\title{
WATER USE IN CAMDEN COUNTY, NEW JERSEY, 1991
}

By John P. Nawyn

U.S. GEOLOGICAL SURVEY

Open-File Report 97-12

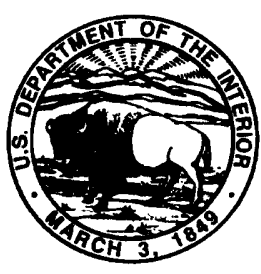

Prepared in cooperation with the NEW JERSEY DEPARTMENT OF ENVIRONMENTAL PROTECTION

West Trenton, New Jersey 


\title{
U.S. DEPARTMENT OF THE INTERIOR \\ BRUCE BABBITT, Secretary
}

\author{
U.S. GEOLOGICAL SURVEY
}

Gordon P. Eaton, Director

For additional information

write to:

District Chief

U.S. Geological Survey

Mountain View Office Park

810 Bear Tavern Road

West Trenton, NJ 08628
Copies of this report can be purchased from:

U.S. Geological Survey

Branch of Information Services

Box 25286

Denver, CO 80225-0286 


\section{CONTENTS}

Abstract

Introduction

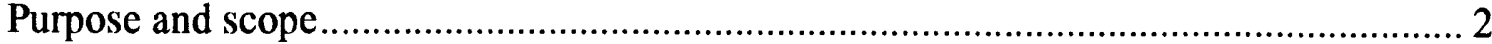

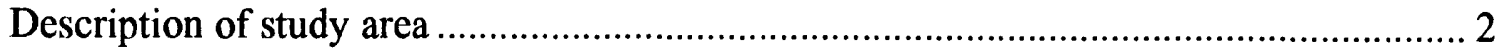

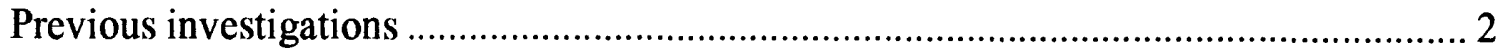

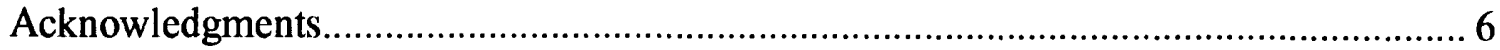

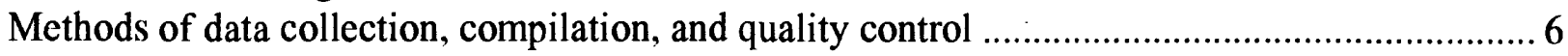

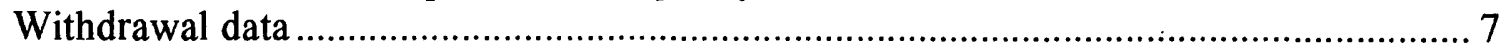

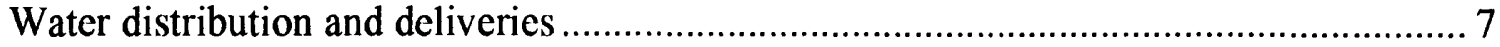

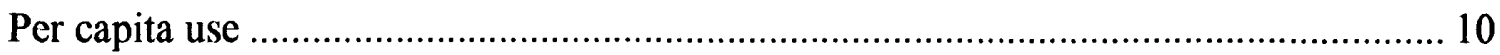

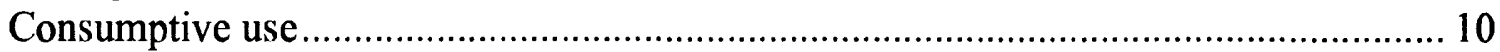

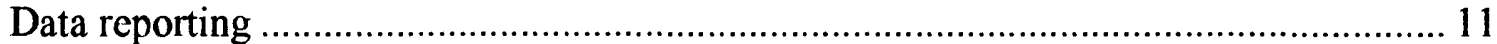

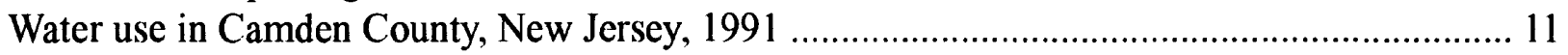

Withdrawals of ground water and surface water by category of use ............................. 11

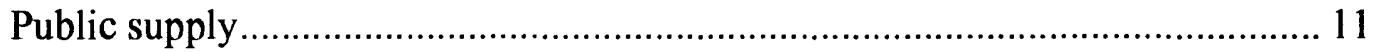

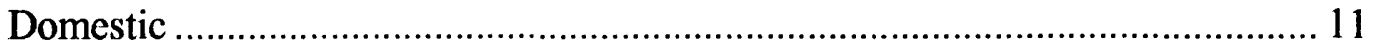

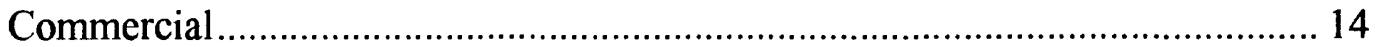

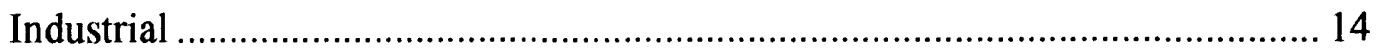

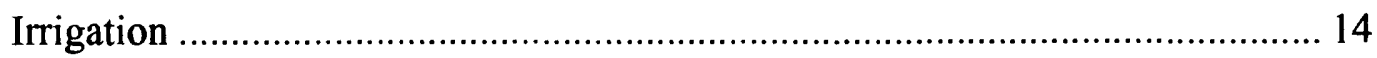

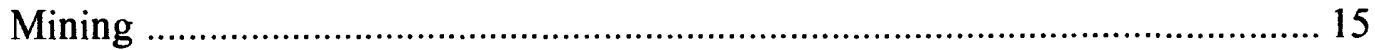

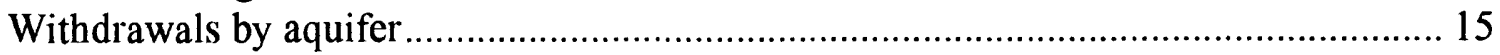

Water distribution and deliveries by public suppliers............................................... 15

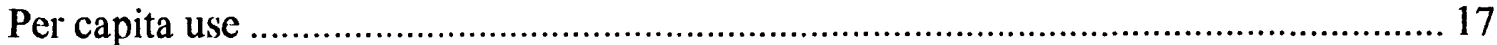

Estimates based on public-supply withdrawal data ......................................... 21

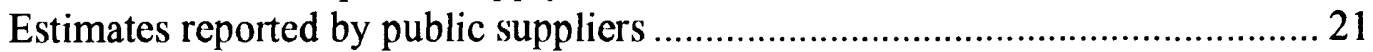

Estimates reported nationally and in other studies in New Jersey...................... 21

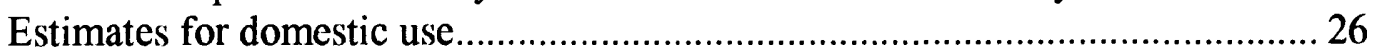

Losses from the water distribution system of public suppliers...................................... 26

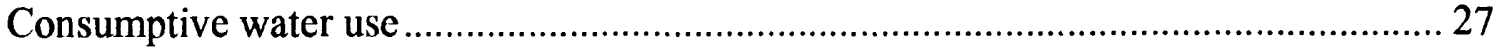

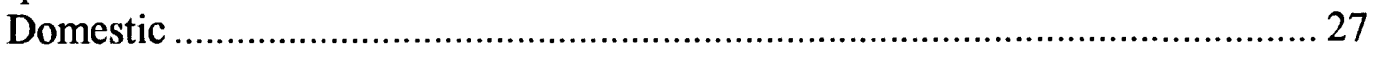

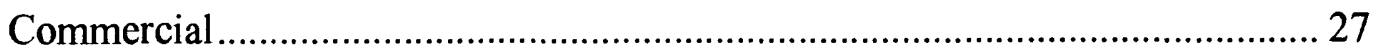

Industrial, irrigation, and mining .................................................................. 29

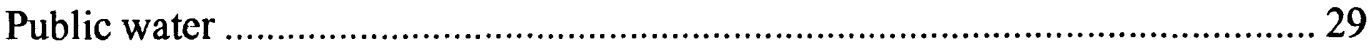

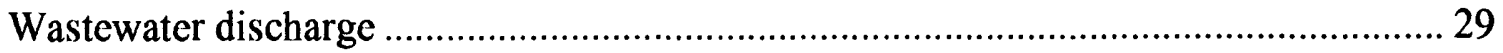

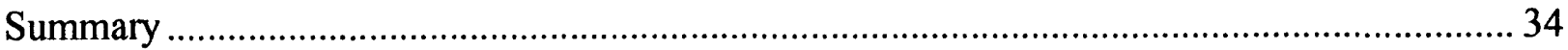

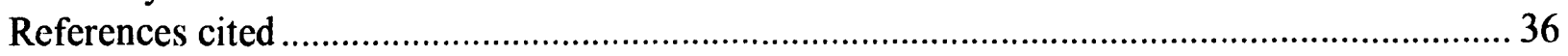

\section{ILLUSTRATIONS}

Figure 1. Map showing location of study area and municipalities in Camden County,

New Jersey 3

2. Diagram showing generalized model of water use .............................................. 8 


\section{ILLUSTRATIONS--Continued}

Figure3-8. Graphs showing:

3. Withdrawals in Camden County, New Jersey, 1991

4. Water deliveries of selected public suppliers in New Jersey, by category of use, reported in percent 18

5. Water deliveries and consumptive use in Camden County, New Jersey, by category of use, 1991

6. Domestic and other deliveries, and per capita use in Camden County, New Jersey, by time period, 1991

7. Per capita use and population served in Camden County, New Jersey, reported by public supplier, 1991

8. Map showing municipal wastewater treatment facilities in Camden County, New Jersey, 1990-91

9. Diagram showing generalized summary of water use in Camden County, New Jersey, 1991

\section{TABLES}

Table 1. Population of Camden County, New Jersey, by municipality and public supplier, source of water, and type of wastewater treatment, 1990.

2. Sources of data on water use in New Jersey...

3. Withdrawals in Camden County, New Jersey, by type of water and category of use, 1991

4. Water distribution and losses in Camden County, New Jersey, by public supplier, 1991

5. Water deliveries and water distribution in Camden County, New Jersey, by public supplier and use, 1991.

6. Per capita water use in Camden County, New Jersey, by public supplier, reported by public supplier and estimated from total withdrawals, metered deliveries, and domestic deliveries, 1991

7. Estimated urban water use in Camden County, New Jersey, for a family of four ........ 25

8. Consumptive use of public-supply and self-supply users in Camden County, New Jersey, by category of use, 1991

9. Municipal wastewater treatment facilities and wastewater discharges in Camden County, New Jersey, 1990-91

10. Withdrawals of ground water and surface water, consumptive and nonconsumptive use, unaccounted-for water, and wastewater treatment and disposal in Camden County, New Jersey, 1991 


\section{CONVERSION FACTORS}

Multiply

inch (in.)

mile (mi)

acre

square foot $\left(\mathrm{ft}^{2}\right)$

square mile $\left(\mathrm{mi}^{2}\right)$

gallon (gal)

million gallons (Mgal)

gallon per day (gal/d)

million gallons per day (Mgal/d)
By

Length

25.4

1.609

$\underline{\text { Area }}$

4,047

0.09294

2.590

$\underline{\text { Volume }}$

$\begin{array}{ll}0.003785 & \text { cubic meter } \\ 3,785 & \text { cubic meter }\end{array}$

Flow

0.003785

0.0438
To obtain

millimeter

kilometer

square meter

square meter

square kilometer cubic meter per day

cubic meter per second 


\title{
WATER USE IN CAMDEN COUNTY, NEW JERSEY, 1991
}

\author{
By John P. Nawyn
}

\begin{abstract}
Withdrawals of ground water and surface water in Camden County in 1991 totaled $76 \mathrm{Mgal} / \mathrm{d}$ (million gallons per day), including about $71 \mathrm{Mgal} / \mathrm{d}$ of ground water and about 5 $\mathrm{Mgal} / \mathrm{d}$ of surface water. Withdrawals of ground water by public suppliers totaled $67 \mathrm{Mgal} / \mathrm{d}$. Self-supplied industrial water use, chiefly surface water from the Delaware River, totaled about $4 \mathrm{Mgal} / \mathrm{d}$. Domestic and irrigation withdrawals totaled about $2 \mathrm{Mgal} / \mathrm{d}$ each. Mining water use totaled about $1 \mathrm{Mgal} / \mathrm{d}$, and commercial water use was less than $1 \mathrm{Mgal} / \mathrm{d}$. Most of the withdrawals of ground water in the county were from the Potomac-Raritan-Magothy aquifer system, chiefly from the Lower aquifer.
\end{abstract}

About 80 percent of public-supply withdrawals are metered deliveries; the balance of the water is chiefly unmetered public water use (municipal) and distribution losses. Deliveries include metered water, public water use, and bulk sales to other public suppliers. About 99 percent of public-supply withdrawals in the county in 1991 received water treatment; the balance is untreated water that was used for backwashing of pumping equipment and other wellmaintenance operations. The distribution losses of public-supply systems in the county were estimated to be $9 \mathrm{Mgal} / \mathrm{d}$. Consumptive water use of all water users in Camden County was estimated to total about $12 \mathrm{Mgal} / \mathrm{d}$; nonconsumed water totaled about $64 \mathrm{Mgal} / \mathrm{d}$.

Discharges by municipal wastewater facilities totaled $58 \mathrm{Mgal} / \mathrm{d}$ in 1991 . Onsite wastewater treatment was estimated to be $10 \mathrm{Mgal} / \mathrm{d}$. The difference in the volume of nonconsumptive water and the volume discharged at wastewater treatment systems in the county was estimated to be $3 \mathrm{Mgal} / \mathrm{d}$. The additional water in the wastewater treatment systems could be inflow from storm sewers or ground water and additional nonconsumed water from public water users.

\section{INTRODUCTION}

In 1986, the New Jersey Department of Environmental Protection (NJDEP) designated the Camden County metropolitan area as a water-supply critical area. (Qualls and Horn, 1990; Navoy, 1994). For decades, ground-water levels declined and created large regional cones of depression in the Camden County area. As a result, contaminants migrated and posed a threat to the Potomac-Raritan-Magothy aquifer system, the chief source of ground water in the county (Ervin and others, 1994). One of the projected remedies to the water crises in the county was the importation of surface water from the Delaware River in Burlington County to communities in Burlington, Camden, and Gloucester Counties. Another change was regionalization of wastewater treatment in Camden County. Many smaller municipal wastewater treatment facilities have closed, and flows in the receiving streams have diminished (R. D. Schopp, U.S. Geological Survey, oral comm., 1995). 
The study described here was done as part of the cooperative water-use program of the U.S. Geological Survey (USGS) and the NJDEP; this program collects and stores water-use data in the Site-Specific Water-Use Data System (SSWUDS) and the Aggregate Water-Use Data System data bases of the Water-Use Data System component of the National Water Information System, the USGS national water-data storage and retrieval system.

\section{Purpose and Scope}

This report describes the results of a study that examined the use of water from withdrawal to return (receiving stream or onsite disposal) in Camden County, New Jersey, in 1991. The categories of water use include public supply, domestic, commercial, industrial, irrigation, and mining. In addition, withdrawals of ground water are compiled by aquifer. Water deliveries of public suppliers are classified as domestic, commercial, industrial, and public water use. Data on withdrawals, water distribution losses of public-supply systems, and municipal wastewater discharges were compiled from reports submitted to the NJDEP and the U.S. Environmental Protection Agency (USEPA).

Coefficients of the deliveries of publicly supplied water by category of use, consumptive and nonconsumptive use of water for all water users in the county, and per capita use of domestic users were developed. In addition, the volume of water withdrawn was compared to the volume of water discharged as wastewater in the county.

\section{Description of Study Area}

Camden County is in southwestern New Jersey and is bounded on the west by Philadelphia, $\mathrm{Pa}$., and the Delaware River and on the east by Atlantic and Burlington Counties (fig. 1). Camden County has 37 municipalities (fig.1), is the fifth smallest county $\left(222 \mathrm{mi}^{2}\right)$ in area, and has the fifth largest population $(505,800)$ in the State (U.S. Bureau of the Census, 1991). The population of Camden County increased by about 7 percent between 1980 and 1990 (U.S. Bureau of the Census, 1991).

Camden County comprises three general regions. The western region of the county is urban and industrial. This region includes the municipalities with the largest population, Camden City $(87,500)$ and Cherry Hill Township $(69,300)$ (fig. 1, table 1). The central region of the county is residential; many residents commute to Philadelphia, Pa. Public suppliers and municipal wastewater facilities serve the western and central regions of the county. The eastern region is rural and includes orchards and vegetable farms. Most of the residents of the rural areas of the county have private water-supply and wastewater treatment systems (table 1).

\section{Previous Investigations}

Vermeule (1894) compiled withdrawal data on public suppliers in the first comprehensive report on withdrawals of ground water and surface water in the State. Hazen, Wipple, and Fuller (1922) and the New Jersey Water Policy Commission (1926) describe sources, consumption, and development of potable water supplies in New Jersey. Tippetts-Abbett-McCartney-Stratton (1955) compiled public-supply withdrawal data for the New Jersey Legislative Commission on 


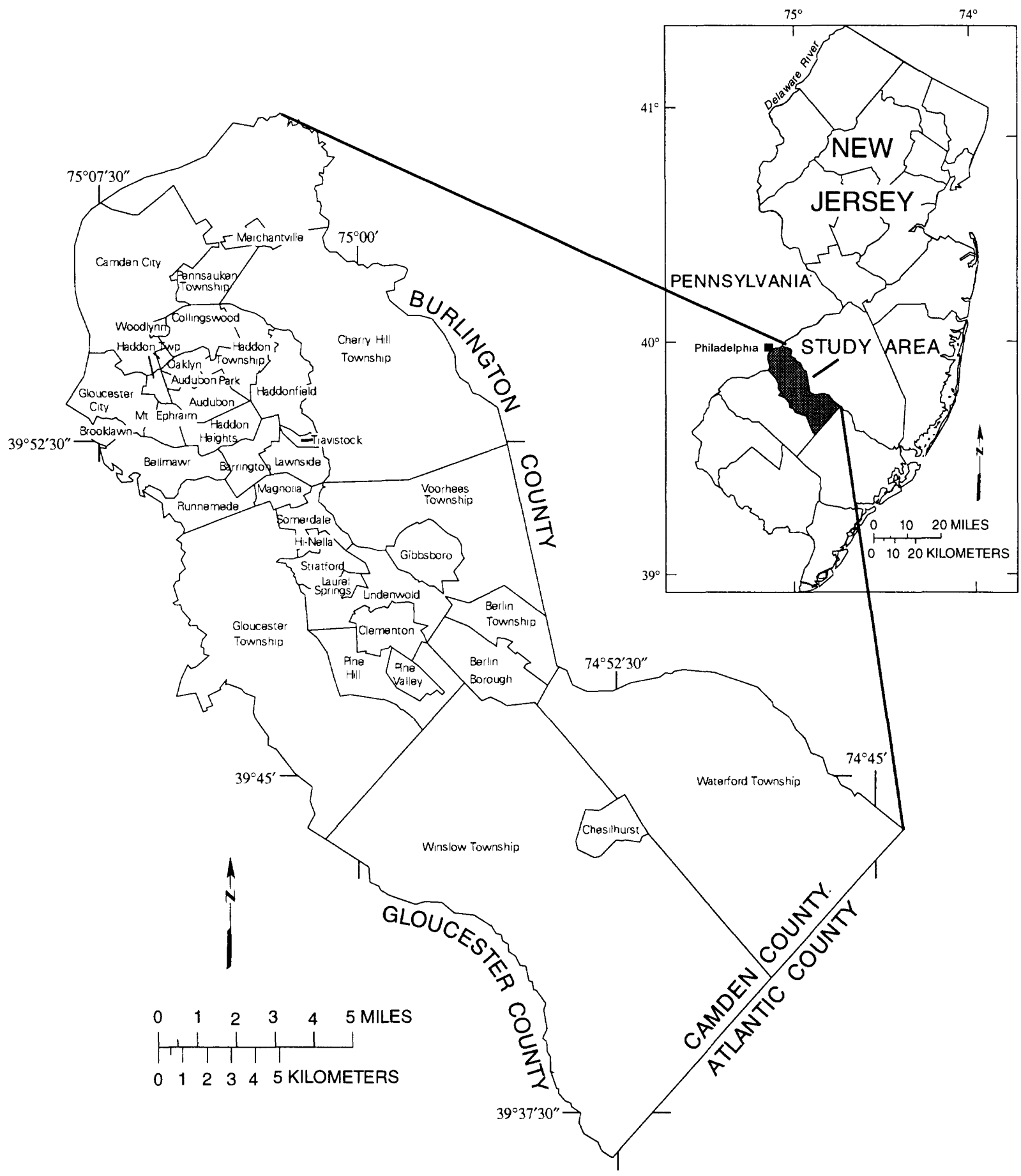

Figure 1. Location of study area and municipalities in Camden County, New Jersey. 


\section{Table 1. Population of Camden County, New Jersey, by municipality and public supplier, source of water, and type of wastewater treatment, 1990}

[Figures may not equal totals because of independent rounding. Population data estimated from U.S. Bureau of the Census, 1993, and Zripko and Hasan, 1994; --, none reported; B, Borough; MUA, Municipal Utilities Authority; NJAWC, New Jersey-American Water Company; Merchantville-Penn, Merchantville-Pennsauken Water Commission; T, Township; WC, Water Company; WD, Water Department; W\&S, Water \& Sewer Department]

\begin{tabular}{|c|c|c|c|c|c|}
\hline \multirow{3}{*}{ Municipality } & \multirow{3}{*}{ Public supplier } & \multicolumn{4}{|c|}{ Population ${ }^{1}$} \\
\hline & & \multicolumn{2}{|c|}{ Source of water ${ }^{2}$} & \multicolumn{2}{|c|}{$\begin{array}{c}\text { Type of wastewater } \\
\text { treatment }\end{array}$} \\
\hline & & $\begin{array}{l}\text { Publicly } \\
\text { supplied }\end{array}$ & Self-supplied & $\begin{array}{l}\text { Publicly } \\
\text { supplied }\end{array}$ & Onsite \\
\hline Audubon & NJAWC & 9,155 & 50 & 9.192 & 13 \\
\hline Audubon Park & NJAWC & 1,147 & -- & 1,150 & -- \\
\hline Barrington & NJAWC & 6.774 & -- & 6.759 & 15 \\
\hline Bellmawr & $\begin{array}{l}\text { Bellmawr WD } \\
\text { N.JAWC }\end{array}$ & 12,603 & -- & 12,570 & 33 \\
\hline Berlin B & Berlin WD & 5.612 & 60 & 5,482 & 190 \\
\hline Berlin T & Berlin WD & 5,266 & 200 & 3,913 & 1.552 \\
\hline Brooklawn & Brooklawn WD & 1.799 & 6 & 1,800 & 5 \\
\hline Camden City & $\begin{array}{l}\text { Camden WD } \\
\text { NJAWC } \\
\text { Merchantville-Penn WC }\end{array}$ & 86,712 & 780 & 86,799 & 693 \\
\hline Cherry Hill T & $\begin{array}{l}\text { NJAWC } \\
\text { Merchantville-Penn WC }\end{array}$ & 68,988 & 360 & 68,726 & 622 \\
\hline Chesilhurst & -. & 236 & 1.290 & 1,045 & 481 \\
\hline Clementon & Clementon WD & 5,601 & -- & 5.466 & 135 \\
\hline Collingswood & Collingswood WD & 15,279 & 10 & 15,259 & 30 \\
\hline Gibbsboro & N.JAWC & 1,883 & 502 & 2,021 & 362 \\
\hline Gloucester City & Gloucester City WD & 10.019 & 2,630 & 12,598 & 51 \\
\hline Gloucester T & $\begin{array}{l}\text { Garden State WC } \\
\text { NJAWC }\end{array}$ & 53,777 & 19 & 56,641 & 1,155 \\
\hline Haddon $\mathrm{T}$ & $\begin{array}{l}\text { NJAWC } \\
\text { Collingswood WD } \\
\text { Haddonfield WD }\end{array}$ & 14,787 & -- & 14,818 & 19 \\
\hline Haddonfield & Haddonfield WD & 11.628 & 50 & 11,623 & 5 \\
\hline Haddon Heights & NJAWC & 7,860 & -- & 7,855 & 5 \\
\hline Hi-Nella & NJAWC & 1,045 & -- & 1,045 & -- \\
\hline
\end{tabular}


Table 1. Population of Camden County, New Jersey, by municipality and public supplier, source of water, and type of wastewater treatment, 1990--Continued

\begin{tabular}{|c|c|c|c|c|c|}
\hline \multirow{3}{*}{ Municipality } & \multirow{3}{*}{ Public supplier } & \multicolumn{4}{|c|}{ Population $^{1}$} \\
\hline & & \multicolumn{2}{|c|}{ Source of water ${ }^{2}$} & \multicolumn{2}{|c|}{$\begin{array}{c}\text { Type of wastewater } \\
\text { treatment }\end{array}$} \\
\hline & & $\begin{array}{l}\text { Publicly } \\
\text { supplied }\end{array}$ & Self-supplied & $\begin{array}{l}\text { Publicly } \\
\text { supplied }\end{array}$ & Onsite \\
\hline Laurel Springs & NJAWC & 2,331 & 10 & 2,337 & 4 \\
\hline Lawnside & NJAWC & 2,661 & 180 & 2,815 & 26 \\
\hline Lindenwold & NJAWC & 18,384 & 350 & 18,595 & 139 \\
\hline Magnolia & NJAWC & 4,841 & 20 & 4,857 & 4 \\
\hline Merchantville & $\begin{array}{l}\text { Merchantville- } \\
\text { Penn WC }\end{array}$ & 4,095 & -- & 4,095 & -- \\
\hline Mt. Ephraim & NJAWC & 4,517 & -- & 4,517 & -- \\
\hline Oaklyn & NJAWC & 4,430 & -- & 4,423 & 7 \\
\hline Pennsauken & $\begin{array}{l}\text { Merchantville- } \\
\text { Penn WC } \\
\text { NJAWC }\end{array}$ & 34,738 & -- & 34,678 & 60 \\
\hline Pine Hill & Pine Hill MUA & 9.544 & 310 & 9,656 & 198 \\
\hline Pine Valley & Pine Hill MUA & 19 & -- & 2 & 17 \\
\hline Runnemede & NJAWC & 9.022 & 20 & 8,907 & 135 \\
\hline Somerdale & NJAWC & 5,420 & 20 & 5,428 & 12 \\
\hline Stratford & NJAWC & 7,594 & 20 & 7,609 & 5 \\
\hline Travistock & Haddon T WD & 35 & -- & 35 & -- \\
\hline Voorhees & NJAWC & 23,839 & 720 & 24,285 & 274 \\
\hline Waterford & Garden State WC & 2,770 & 8,170 & 9,065 & 1,875 \\
\hline Winslow & Winslow T W\&S & 19,487 & 10,600 & 25,362 & 4,725 \\
\hline Woodlynne & Collingswood WD & 2,547 & -- & 2,533 & 14 \\
\hline County total & -- & 476,400 & 26,400 & 490,000 & 12,900 \\
\hline
\end{tabular}

\footnotetext{
${ }^{1}$ County population reported by U.S. Bureau of the Census (1993) was 505,800.

${ }^{2}$ Source of water and type of wastewater treatment were reported by number of housing units. This figure was multiplied by the average household size of 2.76 for Camden County.
} 
Water Supply. The Camden County Planning Department (1972) provided an overview of waterresources and water supply for the period 1950-70. Data on withdrawals of the Coastal Plain, including Camden County, are summarized by Vowinkel (1984). The NJDEP compiled withdrawal data by county for 1987 (Merend, 1989) and 1988 (Saarela, 1992).

The USGS compiled county-level data for 1989 and 1990 (Nawyn and Clawges, 1995). Zripko and Hasan (1994) studied depletive water use (water withdrawals and wastewater transfers among water basins) in New Jersey and compiled data on the average annual water withdrawals and wastewater discharges during 1986-88. Data on 32 public suppliers in New Jersey were compiled by the American Water Works Association (Vern Achtermann, American Water Works Association, written commun., 1995); information includes ownership, population served, per capita, water production, treatment, distribution pipe, storage tanks, and residential water rates. Agricultural water demands in New Jersey were estimated by Titus and others (1990) for fieldgrown crops and by Clawges and Titus (1993) for crops, livestock, and selected sectors of the food-processing industry.

Previous studies of the ground-water resources of Camden County included Thompson (1932), Barksdale and others (1958), and Farlekas and others (1976). These studies indicated a deepening of the cones of depression in the Potomac-Raritan-Magothy aquifer system and an increase in withdrawals of the aquifer system. Concerned about the effects of increasing groundwater withdrawals by public suppliers in the county, the State of New Jersey hired Camp Dresser $\&$ McKee (1984a,b, 1987) to investigate future water demands and availability in the Camden County area. The consultants recommended a reduction of withdrawals from the PotomacRaritan-Magothy aquifer system. Because of restrictions on ground-water withdrawals in the Camden area, a regional source of water supply for Camden, Burlington, and Gloucester Counties was investigated and developed by the New Jersey-American Water Company (1992).

\section{Acknowledgments}

The author gratefully acknowledges Helve Saarela, Nicole Griscom, Louise Slater, and Richard Kropp of the New Jersey Department of Environmental Protection for their professional guidance in preparing this report, and also the staff for collecting and entering monthly withdrawal data into computer files.

\section{METHODS OF DATA COLLECTION, COMPILATION, AND QUALITY CONTROL}

Tracing the path of water use is data intensive (fig. 2). Information is required on the volume and category of use of the withdrawals, the deliveries and distribution of water by public suppliers, the consumption of water (consumptive use) by water users, and the disposal or discharge of water (wastewater treatment). To understand how water is used, demographic and economic data are needed to identify the water users. Data were compiled from U.S. Bureau of the Census (1983a,b, 1990, 1991, 1992, 1993) reports. Data on water withdrawals and water distribution systems were provided by State water regulatory agencies. The NJDEP supplied Water Allocation Diversion Reports, Water Conservation Plans, and Water Utilization Reports 
(fig. 2; table 2). Municipal wastewater treatment data were compiled from the Permit Compliance System of USEPA. Data on other wastewater treatment and domestic withdrawals were estimated for this report (fig. 2; table 2).

\section{Withdrawal Data}

Water users who have the capacity to withdraw 100,000 gal or greater during a 24 -hour period must obtain permits from the NJDEP. Water users who withdraw $100,000 \mathrm{gal} / \mathrm{d}$ or greater are issued water-allocation permits; lower volume water users (less than 100,000 gal/d) are issued well registrations; and agricultural/horticultural users are issued agricultural certifications (higher volume irrigation users) or agricultural registrations (lower volume irrigation users). Most water users who submit monthly withdrawal data (annually or quarterly) to the NJDEP have inline flowmeters to record the volume of water withdrawn. Water used for agricultural/ horticultural purposes is chiefly unmetered; the water user generally estimates withdrawals as the product of the pump capacity and the pumping time.

Computerized withdrawal data from the NJDEP was transferred to the SSWUDS data base of the USGS. For quality assurance of the site and withdrawal data in the NJDEP and the USGS computer files, USGS software was used to identify new withdrawal sites. New ground-water sites in the NJDEP files that were entered into the Ground-Water Site Inventory (GWSI) data base of the USGS and new surface-water sites were entered into National Water Information System (NWIS) data base of the USGS. All new sites were also entered into the SSWUDS data base.

Annual withdrawal data in 1990 were compared with 1991 withdrawal data. The USGS quality assurance program used to identify new withdrawal sites was also used to compare the annual withdrawal data for each withdrawal site; a 1 percent error tolerance was allowed. Matched withdrawal data were entered into SSWUDS. Data collection forms were generated and used to verify unmatched site or withdrawal data before the data were entered in the USGS data bases.

Public-supply withdrawal data in the SSWUDS and the NJDEP data bases were consistent; however, withdrawal data reported as an annual or quarterly value in Water Conservation Plans and Water Utilization Reports of the NJDEP did not always agree with data in the USGS and NJDEP data bases. The withdrawal values reported in Water Utilization Reports were used to determine water deliveries, distribution losses, unaccounted-for water, public water use, and consumptive use. Water Conservation Plans were used to verify some of these data. Water-use data for self-supplied users were determined from withdrawal data reported in the USGS and NJDEP data bases.

\section{Water Distribution and Deliveries}

Water distribution is the pathway or movement of water through the water conveyance system of the public supplier, and water deliveries are the sales of metered and unmetered water. Data on the general distribution of water by most public suppliers in Camden County were available from the NJDEP. The deliveries of publicly supplied water by category of use were estimated by applying coefficients developed from data on water deliveries of the largest water 


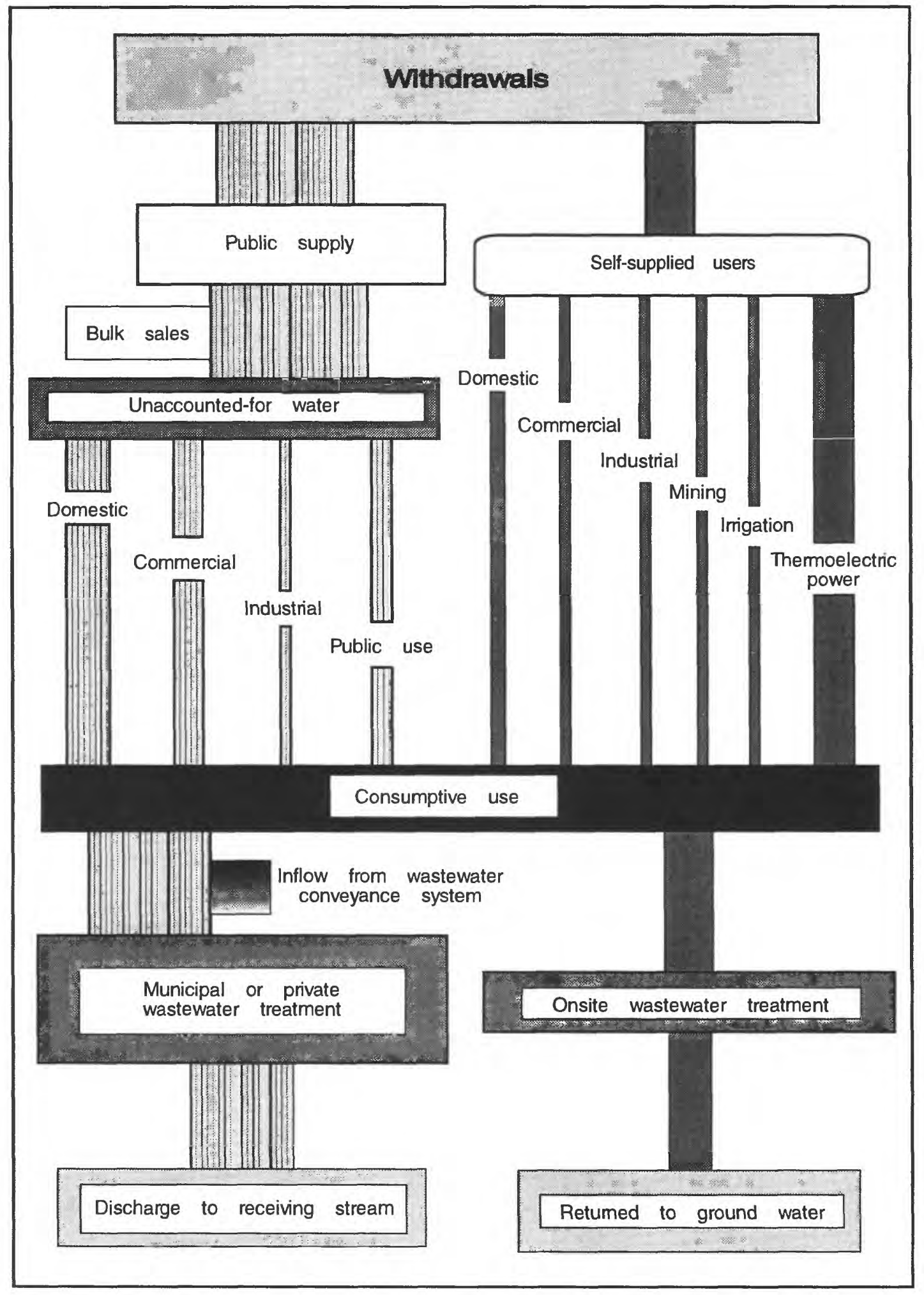

Figure 2. Generalized model of water use. 
[Data on file at the New Jersey Department of Environmental Protection (NJDEP); gal/min, gallons per minute; gal/d, gallons per day]

\begin{tabular}{|c|c|c|c|}
\hline Type of data & Type of withdrawal sites & Type of data reported & $\begin{array}{l}\text { Frequency of data } \\
\text { reporting }\end{array}$ \\
\hline \multicolumn{4}{|c|}{ U.S. Geological Survey } \\
\hline $\begin{array}{c}\text { Site-Specific Water- } \\
\text { Use Data System }\end{array}$ & $\begin{array}{l}\text { All water users with } \\
\text { pumping equipment capable } \\
\text { of producing } 70 \mathrm{gal} / \mathrm{min} \text { or } \\
\text { greater and small public } \\
\text { suppliers }\end{array}$ & $\begin{array}{l}\text { Monthly withdrawals } \\
\text { Source of water } \\
\text { Category of use } \\
\text { Withdrawals by aquifer }\end{array}$ & $\begin{array}{l}\text { Monthly } \\
\text { withdrawals and } \\
\text { estimated } \\
\text { annual } \\
\text { withdrawals } \\
\text { (domestic } \\
\text { supply) }\end{array}$ \\
\hline \multicolumn{4}{|c|}{ NJDEP, Bureau of Water Allocation } \\
\hline $\begin{array}{l}\text { Water Supply } \\
\text { Diversion } \\
\text { Reports }\end{array}$ & $\begin{array}{l}\text { All water users with pumping } \\
\text { equipment capable of } \\
\text { producing } 70 \mathrm{gal} / \mathrm{min} \text { or } \\
\text { greater }\end{array}$ & $\begin{array}{l}\text { Monthly withdrawals } \\
\text { Source of water }\end{array}$ & $\begin{array}{l}\text { Monthly } \\
\text { withdrawals } \\
\text { reported } \\
\text { quarterly or } \\
\text { annually }\end{array}$ \\
\hline $\begin{array}{l}\text { Water Conservation } \\
\text { Plans }\end{array}$ & $\begin{array}{l}\text { Water-supply systems and } \\
\text { large-volume (more than } \\
100,000 \mathrm{gal} / \mathrm{d} \text { ) water users } \\
\text { including industrial and } \\
\text { commercial users }\end{array}$ & 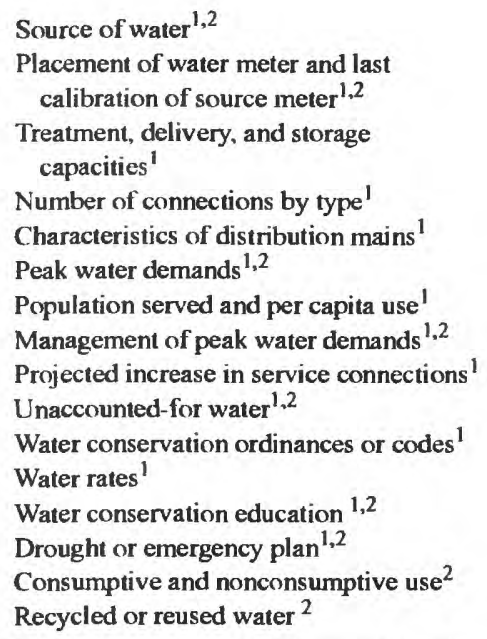 & $\begin{array}{l}\text { Water Conservation } \\
\text { Plans updated } \\
\text { annually }\end{array}$ \\
\hline \multicolumn{4}{|c|}{ NIDEP, Bureau of Safe Drinking Water } \\
\hline $\begin{array}{l}\text { Water Utilization } \\
\text { Reports }\end{array}$ & Most public suppliers & $\begin{array}{l}\text { Withdrawals or bulk purchase } \\
\text { Volume of water after water treatment } \\
\text { Volume of water at metered points of } \\
\text { distribution system } \\
\text { Volume of water at unmetered points of } \\
\text { distribution system } \\
\text { Bulk sales } \\
\text { Lost or unaccounted-for water }\end{array}$ & $\begin{array}{l}\text { Withdrawal data } \\
\text { reported } \\
\text { quarterly and } \\
\text { annually } \\
\text { Reports update } \\
\text { annually }\end{array}$ \\
\hline
\end{tabular}

U.S. Bureau of the Census

\begin{tabular}{cll}
\hline $\begin{array}{l}\text { Source of water supply } \\
\text { Type of wastewater treatment }\end{array}$ & Every 10 years & Every 10 years \\
\hline U.S. Environmental Protection Agency & Annually \\
\hline & $\begin{array}{l}\text { Permit Compliance System tracks } \\
\text { information about wastewater treatment } \\
\text { facilities. } \\
\text { Industrial Facilities Discharge File tracks } \\
\text { information on private company and } \\
\text { municipal point source dischargers to } \\
\text { surface water. }\end{array}$ \\
\hline
\end{tabular}

1 Water Supply Diversion Reports.

2 Water Conservation Plans. 
supplier in Camden County and another large public supplier in New Jersey. Data on unaccounted-for water and public water use were compiled from data reported to the NJDEP. The coefficients were applied to data on public-supply withdrawals in the county to estimate domestic, commercial, and industrial deliveries. When industrial deliveries were not reported, domestic deliveries were increased by the volume that would have been assigned to industrial deliveries. The presence of industrial users was verified by data on service connections reported in Water Conservation Plans.

\section{Per Capita Use}

The term "per capita use" is simply defined as the volume of water used by each person. In Camden County, the per capita use of self-supplied and publicly supplied residential users are assumed to be similar. The use of water by residents of single-family housing units with private wells is similar to the use of water by residents of single-family housing units in nearby publicly supplied communities. Environmental variables such as temperature and rainfall show little, if any, variation between areas of self-supplied and publicly supplied water users. In some suburban areas, residential neighborhoods are composed of publicly supplied and self-supplied households. The size of households and incomes of residents of publicly supplied and self-supplied singlefamily housing units also are similar in Camden County (U.S. Bureau of the Census, 1992).

The per capita use of publicly supplied residents can be estimated on the basis of the total volume withdrawn by public suppliers or the domestic deliveries by public suppliers. In this report, both methods are used and compared with per capita use previously reported in New Jersey and national studies. Many public suppliers estimate per capita use by dividing the total volume of water deliveries by the number of people served by the water system. Although most publicly supplied water is chiefly for domestic use, other uses and distribution losses that are included in total withdrawal values can artificially increase the per capita value. Domestic deliveries were estimated from coefficients that were developed by the author and were based on water deliveries and water-distribution losses reported by large public suppliers in New Jersey.

The values for per capita use in Camden County were estimated by use of several methods including (1) dividing the monthly and annual withdrawal data reported by public suppliers by U.S. Bureau of the Census (1992) population data on source of water, (2) analyzing data on per capita use reported by public suppliers in the county, and (3) applying data on household water use reported in national studies that include per capita use.

\section{Consumptive Use}

Consumptive use is defined as that part of water withdrawn that is evaporated, transpired, or incorporated into crops or products (Solley and others, 1993). For example, water used for toilet flushing is a nonconsumptive use because the water can be available for other uses (such as public supply, irrigation, or process water for industrial users) after treatment at a wastewater treatment facility; however, water applied to a backyard garden or field crops is chiefly consumptive use because the water is incorporated into crops. Consumptive use was estimated for both publicly supplied and self-supplied water users. Coefficients of consumptive water use that were developed in other studies were modified and applied to data on water users in Camden County. 


\section{Data Reporting}

Generally, values reported in the text were rounded to whole numbers or three significant figures, except for coefficients and some values less than $1 \mathrm{Mgal} / \mathrm{d}$ that are reported to two decimal places. County total data from U.S. Bureau of the Census (table 1) on the population of publicly supplied and self-supplied residents of Camden County are rounded to the nearest hundred. Figures may not add up to totals because of independent rounding.

\section{WATER USE IN CAMDEN COUNTY, NEW JERSEY, 1991}

Public suppliers have been one of the chief users of water in Camden County throughout most of its history. From 1853 to 1898 , the city of Camden withdrew as much as $10 \mathrm{Mgal} / \mathrm{d}$ from the Delaware River (Vermeule, 1894; Thompson, 1932). This untreated surface water, associated with frequent epidemics of typhoid fever and other water-borne illnesses, was replaced by the development of ground-water resources along the Delaware River (Thompson, 1932). For nearly 100 years, the Potomac-Raritan-Magothy aquifer system in Camden County has been the chief source of water for most water uses in the county. Withdrawals in Camden County in 1991 totaled $76 \mathrm{Mgal} / \mathrm{d}$ (71 Mgal/d of ground water and $5 \mathrm{Mgal} / \mathrm{d}$ of surface water) (fig. 3a; table 3).

\section{Withdrawals of Ground Water and Surface Water by Category of Use}

For this report, withdrawals of ground water and surface water are grouped into six categorics: public supply, domestic, commercial, industrial, irrigation, and mining.

\section{Public Supply}

A public-supply system serves at least 25 people or has a minimum of 15 service connections (Solley and others, 1993). Camden County has 23 public-supply systems: 12 municipal, 3 investor-owned, 6 small community public-supply systems (mobile home parks), and 2 self-supplied institutions (unpublished data are on file at New Jersey Department of Environmental Protection, Trenton, N.J.). About 95 percent of the county residents $(476,400)$ are served by public suppliers (table 1). Public supply, the chief use of water in Camden County, totaled $67 \mathrm{Mgal} / \mathrm{d}$ in 1991 (fig. 3a; table 3).

All withdrawals for public supply in Camden County are ground water. Withdrawals from the Potomac-Raritan-Magothy aquifer system totaled about $60 \mathrm{Mgal} / \mathrm{d}$ in 1991. The Lower aquifer was the chief source of public-supply withdrawals in the county. Public-supply withdrawals from the Kirkwood-Cohansey aquifer system and Wenonah-Mount Laurel aquifer were about $2 \mathrm{Mgal} / \mathrm{d}$ each.

\section{Domestic}

Withdrawals by self-supplied domestic users in Camden County were estimated to be $2 \mathrm{Mgal} / \mathrm{d}$ of ground water (fig. 3a; table 3). This volume of water was estimated to be the product of the population of self-supplied residents and the per capita water-use coefficient of $84 \mathrm{gal} / \mathrm{d}$ (see section on "Per Capita Use") for residents of single-family housing units. The population of 
A. Withdrawals of ground water and surface water, by category of use

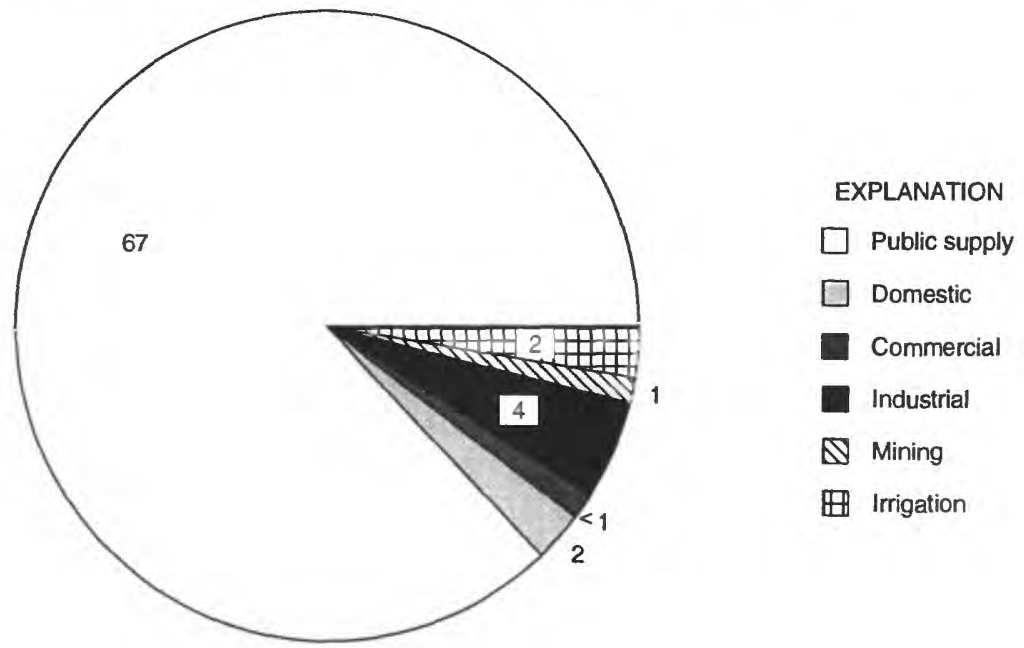

B. Withdrawals by aquifer

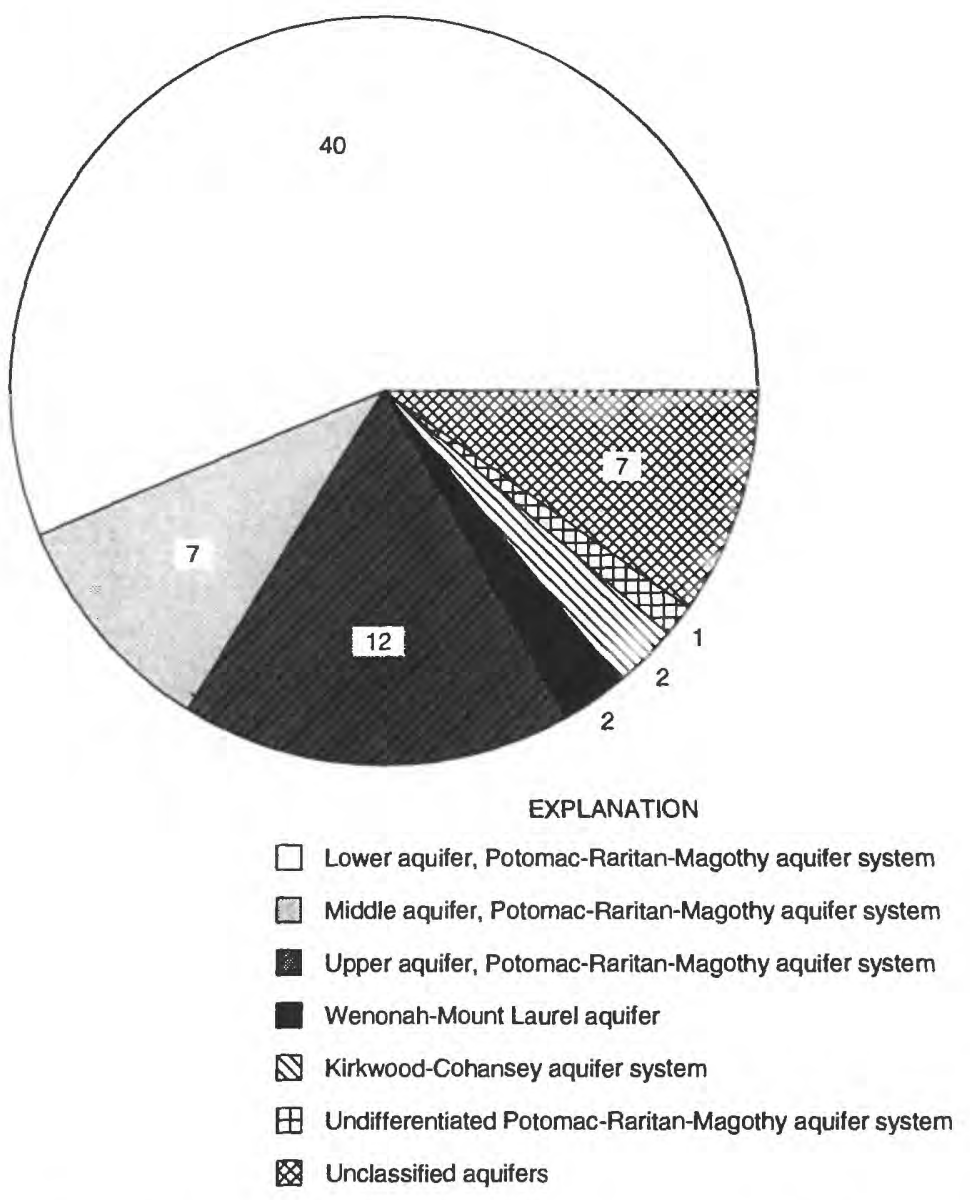

Figure 3. Withdrawals in Camden County, New Jersey, 1991. (Withdrawals in million gallons per day) 
Table 3. Withdrawals in Camden County, New Jersey, by type of water and category of use, 1991

[Figures may not add to totals because of independent rounding; --, no values reported.]

\begin{tabular}{lrrrrrr}
\hline & \multicolumn{5}{c}{ Withdrawals, in million gallons per day } \\
\cline { 2 - 7 } Water-use category & \multicolumn{2}{c}{ Ground water } & \multicolumn{2}{c}{ Surface water } & \multicolumn{2}{c}{ Total } \\
\hline Public supply & 67 & $(94 \%)$ & -- & $(--)$ & 67 & $(88 \%)$ \\
Domestic & 2 & $(3 \%)$ & -- & $(--)$ & 2 & $(3 \%)$ \\
Commercial & $<1$ & $(--)$ & -- & $(--)$ & $<1$ & $(1 \%)$ \\
Irrigation & 2 & $(3 \%)$ & $<1$ & $(6 \%)$ & 2 & $(3 \%)$ \\
Mining & $<1$ & $(--)$ & 1 & $(18 \%)$ & 1 & $(1 \%)$ \\
Industrial & $<1$ & $(--)$ & 4 & $(76 \%)$ & 4 & $(5 \%)$ \\
\cline { 2 - 7 } Total & 71 & $(100 \%)$ & 5 & $(100 \%)$ & 76 & $(100 \%)$ \\
\hline
\end{tabular}


self-supplied domestic users in 1990 was estimated to be about 26,400 (table 1). Most of the withdrawals by self-supplied domestic users were presumed to be from shallow wells (less than $100 \mathrm{ft}$ ) in the Kirkwood-Cohansey aquifer system.

\section{Commercial}

Withdrawals of ground water for self-supplied commercial use totaled about $1 \mathrm{Mgal} / \mathrm{d}$ (fig. 3a; table 3). Most commercial establishments in the county are served by public suppliers. The commercial establishments in Camden County include wholesale trade $(1,100)$; retail trade $(2,900)$; finance, insurance, and real estate $(1,000)$; services $(4,400)$; and transportation and public utilities (416). The total employment of commercial establishments was 132,000 in 1991 (U.S. Bureau of the Census, 1990, 1993).

\section{Industrial}

Withdrawals of ground water for self-supplied industrial use in Camden County were less than $1 \mathrm{Mgal} / \mathrm{d}$, and withdrawals of surface water totaled $4 \mathrm{Mgal} / \mathrm{d}$ (fig. 3a; table 3). In 1991, of the 684 industrial facilities in the county, about 64 percent (440) employed less than 20 employees. The largest manufacturing groups were printing and publishing, industrial machinery and equipment, and fabricated metals, representing 24,15 , and 11 percent, respectively, of all industrial users in the county. The total employment of industrial establishments was 25,400 (U.S. Bureau of the Census, 1990, 1993).

Self-supplied industrial water users include 12 facilities: 10 ground-water users and 2 surface-water users. Self-supplied industrial users represent about 2 percent of all industrial use in Camden County. Most industries in the county purchase water from public suppliers (for drinking water, sanitary services, and other purposes for which water of high quality is required) and discharge the wastewater through municipal wastewater treatment facilities. About 20 industrial users discharge wastewater to the Delaware River or local streams (U.S. Environmental Protection Agency, Permit Compliance System, data on file at the U.S. Geological Survey, Branch of Water Use, Reston, Va.).

\section{Irrigation}

Withdrawals of ground water for irrigation use totaled about $2 \mathrm{Mgal} / \mathrm{d}$ and withdrawals of surface water were less than $1 \mathrm{Mgal} / \mathrm{d}$ (fig. 3a; table 3). Most of the water used for irrigation in the county is for agricultural purposes. The chief agricultural products include nursery and greenhouse crops, vegetables, and fruits, nuts, and berries. (U.S. Bureau of the Census, 1994a). In 1991, there were 57 agricultural/horticultural certifications in use in the county. Nonagricultural irrigation users (chiefly golf courses) represent 17 percent of all irrigation use in the county.

About 6,300 acres of cropland were reported in 1992, about 2,500 acres of which were irrigated (U.S. Bureau of the Census, 1994a). Most of the withdrawals by agricultural users were from shallow wells (less than $100 \mathrm{ft}$ ) in the Kirkwood-Cohansey aquifer system. 


\section{Mining}

Withdrawals for mining use totaled more than $1 \mathrm{Mgal} / \mathrm{d}$ (fig. 3a; table 3). Surface-water withdrawals were about than $1 \mathrm{Mgal} / \mathrm{d}$, and ground-water withdrawals were less than $1 \mathrm{Mgal} / \mathrm{d}$. Water used for mining in Camden County is for sand and gravel production (Harrison, 1988).

\section{Withdrawals by Aquifer}

Total withdrawals of ground water in Camden County were $71 \mathrm{Mgal} / \mathrm{d}$ in 1991 . Withdrawal data and aquifer designations were obtained from the SSWUDS data base. Not all withdrawal sites in the data base had aquifer designations. Withdrawals from the Potomac-Raritan-Magothy aquifer system totaled about $60 \mathrm{Mgal} / \mathrm{d}$, including withdrawals from the Lower aquifer (40 Mgal/d), the Middle aquifer ( $7 \mathrm{Mgal} / \mathrm{d}$ ), the Upper aquifer (12 Mgal/d), and undifferentiated aquifers (1 Mgal/d) of the aquifer system (fig. $3 \mathrm{~b}$ ).

Withdrawals of the Kirkwood-Cohansey aquifer system and the Wenonah-Mount Laurel aquifer totaled $2 \mathrm{Mgal} / \mathrm{d}$ each (fig $3 \mathrm{~b}$ ). Aquifer designations for about $7 \mathrm{Mgal} / \mathrm{d}$ of withdrawals were unknown; however, these withdrawals, primarily domestic-supply and agricultural use, are presumed to be primarily from the Kirkwood-Cohansey aquifer system.

\section{Water Distribution and Deliveries by Public Suppliers}

Data on the general distribution of water by most public suppliers in Camden County were available from the NJDEP. The data include the volume of water that is (1) withdrawn (raw water), (2) chemically treated (treated water), (3) delivered (distributed water) as metered sales to customers, (4) metered or unmetered sales for municipal services (public water use), and (5) sold to other public suppliers (bulk sales) (table 4). Most raw water is treated (99 percent) and distributed as water deliveries (metered sales; 80 percent), public water use (4 percent), and bulk sales ( 1 percent). The balance of the water is lost after entering the water-conveyance system. The data on water distribution (Water Conservation Plans) indicate the number of service connections for each use category but not the volume of water delivered to each category. Data on water distribution were used to estimate the volume of water sales (metered water) and public water use, as well as the losses of the water-conveyance system. Public water use includes water (metered or unmetered) that is used for schools, municipal buildings, recreational facilities, and firefighting.

Time constraints precluded the collection of water delivery (sales) data for all public suppliers in the county; however, water deliveries by use category were estimated by applying coefficients. These coefficients were developed from data on water deliveries of two of New Jersey's chief public suppliers, including the largest water supplier in the county. These coefficients of water deliveries were applied to data on each public supplier compiled from Water Conservation Plans and Water Utilization Reports on file at the NJDEP. 
Table 4. Water distribution and losses in Camden County, New Jersey, by public supplier, 1991

[Figures may not add to totals because of independent rounding. Data on file at the New Jersey Department of Environmental Protection, Trenton, N.J.; all withdrawals in million gallons per day; --, no values reported; <, less than; MUA, Municipal Utilities Authority; NJAWC, New Jersey-American Water Company; Merchantville-Penn, Merchantville-Pennsauken Water Commission; T, Township; WC, Water Company; WD, Water Department; W\&S, Water and Sewer Department]

\begin{tabular}{|c|c|c|c|c|c|c|c|}
\hline \multirow[b]{2}{*}{ Public supplier } & \multicolumn{5}{|c|}{ Type of water distribution } & \multicolumn{2}{|c|}{ Unaccounted-for water } \\
\hline & $\underset{\text { water }}{\text { Raw }}$ & $\begin{array}{l}\text { Treated } \\
\text { water }^{2}\end{array}$ & $\begin{array}{l}\text { Meteręd } \\
\text { water }^{3}\end{array}$ & $\begin{array}{c}\text { Public- } \\
\text { water use }\end{array}$ & $\begin{array}{l}\text { Bulk } \\
\text { sales }^{5}\end{array}$ & Losses & Percentage \\
\hline Bellmawr WD & 1.07 & 1.07 & 0.75 & 0.04 & -- & 0.28 & 26 \\
\hline Berlin WD & 1.42 & 1.41 & 1.41 & $<1$ & $<1$ & -- & $<1$ \\
\hline Brooklawn WD & .25 & .25 & .25 & $<1$ & -- & .01 & 3 \\
\hline Camden City WD & 16.60 & 15.94 & 8.79 & 2.13 & -- & 5.68 & 36 \\
\hline Clementon $\mathrm{WD}^{6}$ & .65 & .60 & .36 & .09 & -- & .20 & 33 \\
\hline Collingswood WD & 2.24 & 2.19 & 2.03 & .01 & -- & .20 & 9 \\
\hline $\begin{array}{l}\text { Garden State WC- } \\
\text { Blackwood }\end{array}$ & 3.62 & 3.62 & 3.41 & .01 & -- & .20 & 6 \\
\hline Gloucester City WD & 1.42 & 1.35 & .97 & .36 & -- & .09 & 7 \\
\hline Haddon T WD & 1.47 & 1.45 & 1.16 & ${ }^{6} .07$ & -- & .24 & 17 \\
\hline Haddonfield WD & 1.21 & 1.04 & 1.04 & .04 & -- & .13 & 13 \\
\hline Merchantville-Penn & 6.85 & 6.82 & 6.49 & .17 & -- & .19 & 3 \\
\hline NJAWC-Camden & 3.47 & 3.47 & 3.24 & .19 & -- & .04 & 2 \\
\hline NJAWC- Haddon & 23.82 & 23.80 & 21.09 & .13 & .79 & 1.81 & 8 \\
\hline Pine Hill MUA ${ }^{6}$ & .85 & ${ }^{6} .83$ & ${ }^{6} .77$ & ${ }^{6} .01$ & - & ${ }^{6} .07$ & ${ }^{6} 8$ \\
\hline Winslow $T \mathrm{~W} \& \mathrm{~S}^{6}$ & 1.83 & ${ }^{6} 1.83$ & ${ }^{6} 1.60$ & ${ }^{6} .04$ & .06 & ${ }^{6} .13$ & $6_{7}$ \\
\hline Total withdrawals & 67 & 66 & 53 & 3 & 1 & 9 & -- \\
\hline $\begin{array}{l}\text { Percentage of all } \\
\text { withdrawals }\end{array}$ & 100 & 99 & 80 & 4 & 1 & 14 & -- \\
\hline $\begin{array}{l}{ }^{1} \text { Data from Water } \\
\text { Protection. } \\
{ }^{2} \text { Water available for } \\
{ }^{3} \text { Water sales to dom } \\
{ }^{4} \text { Unmetered water } \\
{ }^{5} \text { Water sales to othe } \\
{ }^{6} \text { Fstimated from }\end{array}$ & $\begin{array}{l}\text { lization } \mathrm{Re} \\
\text { istribution } \\
\text { itic, comm } \\
\mathrm{d} \text { by muni } \\
\text { oublic supp }\end{array}$ & $\begin{array}{l}\text { and in } \\
\text { facilitie }\end{array}$ & $\begin{array}{l}\text { al custon } \\
\text { ervices. }\end{array}$ & Plans of $\mathrm{Ne}$ & Jersey I & artment of & vironmental \\
\hline
\end{tabular}


Coefficients of water deliveries were generated for 1990-92 water deliveries of the New Jersey-American Water Company (NJAWC) (James Scott, New Jersey-American Water Company, written commun., 1993) and 1993 water deliveries of the Elizabethtown Water Company (EWC) (Edward Cash, Elizabethtown Water Company, written commun., 1994).

The NJAWC data reported commercial water deliveries (31 percent) as the combined deliveries to commercial users and domestic users in multifamily housing ( 3 or more dwelling units). In 1990, an estimated 23,000 multifamily dwelling units (average household size, 2.76) (U.S. Bureau of the Census, 1991) and about 63,480 residents were served by the NJAWC. The per capita use was estimated to be about $56 \mathrm{gal} / \mathrm{d}$, and the total delivery to residents of multifamily housing was estimated to be about $4 \mathrm{Mgal} / \mathrm{d}$. The adjusted NJAWC data show that domestic, commercial, industrial, and public water use averaged $77,16,2$, and 5 percent, respectively, of total water deliveries (distributed water) (fig.4a).

Another pattern of water deliveries is shown in the data on water deliveries in 1993 of the EWC. Increased industrial deliveries and decreased residential deliveries relative to the NJAWC data were reported. Domestic, commercial, industrial, and public water deliveries account for 71 , 16,13 , and less than 1 percent, respectively, of total water deliveries (fig. $4 \mathrm{~b}$ ). Domestic deliveries include users in single-family, duplex, condominium, and multifamily housing units that account for $55,5,3$, and 8 percent, respectively, of total water deliveries (fig. $4 \mathrm{~b}$ ).

Data on water deliveries of the NJAWC and the EWC were analyzed, and coefficients for domestic, commercial, and industrial deliveries were estimated to be $0.77,0.16$, and 0.02 , respectively. These coefficients were applied to the data on metered water in Camden County for 1991. The resulting estimates for domestic, commercial, and industrial deliveries are 44, 9 , and $1 \mathrm{Mgal} / \mathrm{d}$, respectively (fig. 5a; table 5). Public water use accounted for about $3 \mathrm{Mgal} / \mathrm{d}$ (fig. 5a; table 4). If industrial deliveries were not reported in Water Conservation Plans, domestic deliveries were increased by the volume that would have been assigned to industrial deliveries.

\section{Per Capita Use}

The discussion of per capita use is presented at this time because the data on domestic deliveries were used to estimate per capita use of both self-supplied and publicly supplied residents in Camden County. Per capita use is the volume of water received by or for each person. Although per capita use varies in relation to household size, housing density, temperature, rainfall, income, water price, and price structure (Opitz and others, 1994), this report will discuss per capita use in relation to the housing type and the methods of estimating per capita use. Generally, the use of water by residents of multifamily housing units is less than the use of residents of single-family housing units. This difference is related to increased outdoor water use of residents of single-family housing units.

The results of estimating per capita use of publicly supplied residents can vary because public suppliers base per capita use estimates on the volume of (1) total water withdrawn, (2) water distributed to all users (metered deliveries), or (3) water distributed to domestic users. Data on the population served by public suppliers are rarely based on an enumeration of users but are estimated primarily as the number of service connections multiplied by an average household size for the area. The publicly supplied population of Camden County was estimated to be 476,400 (U.S. Bureau of the Census, 1992; 1993). 
A. New Jersey-American Water Company, 1990-92, reported as an average and by division

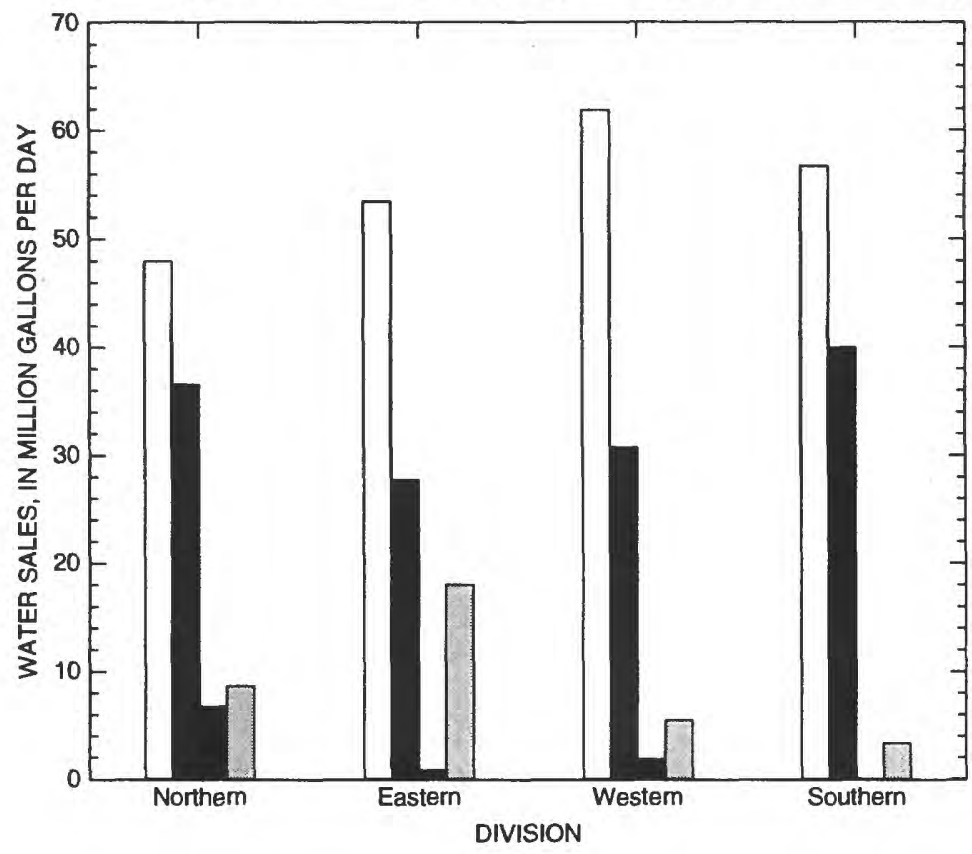

EXPLANATION

$\square$ Domestic

Commercial

Industrial

Public use and distribution losses

B. Elizabethtown Water Company, 1993

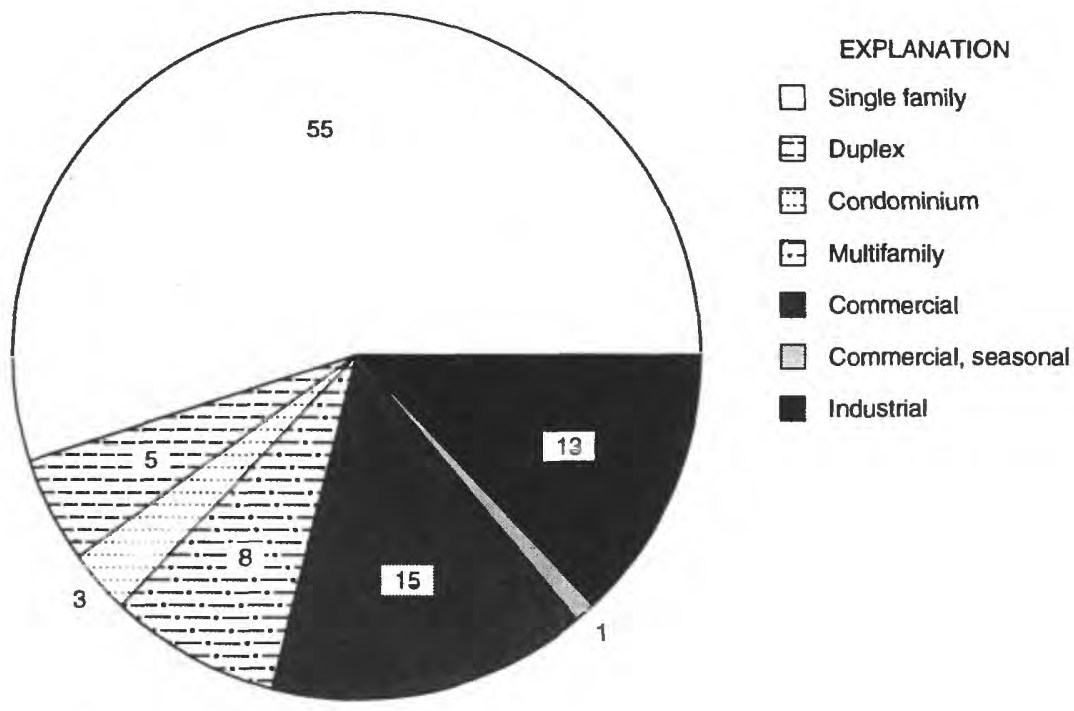

Figure 4. Water deliveries of selected public suppliers in New Jersey, by category of use, reported in percent. (Data reported by public suppliers) 
A. Water deliveries by public supplier

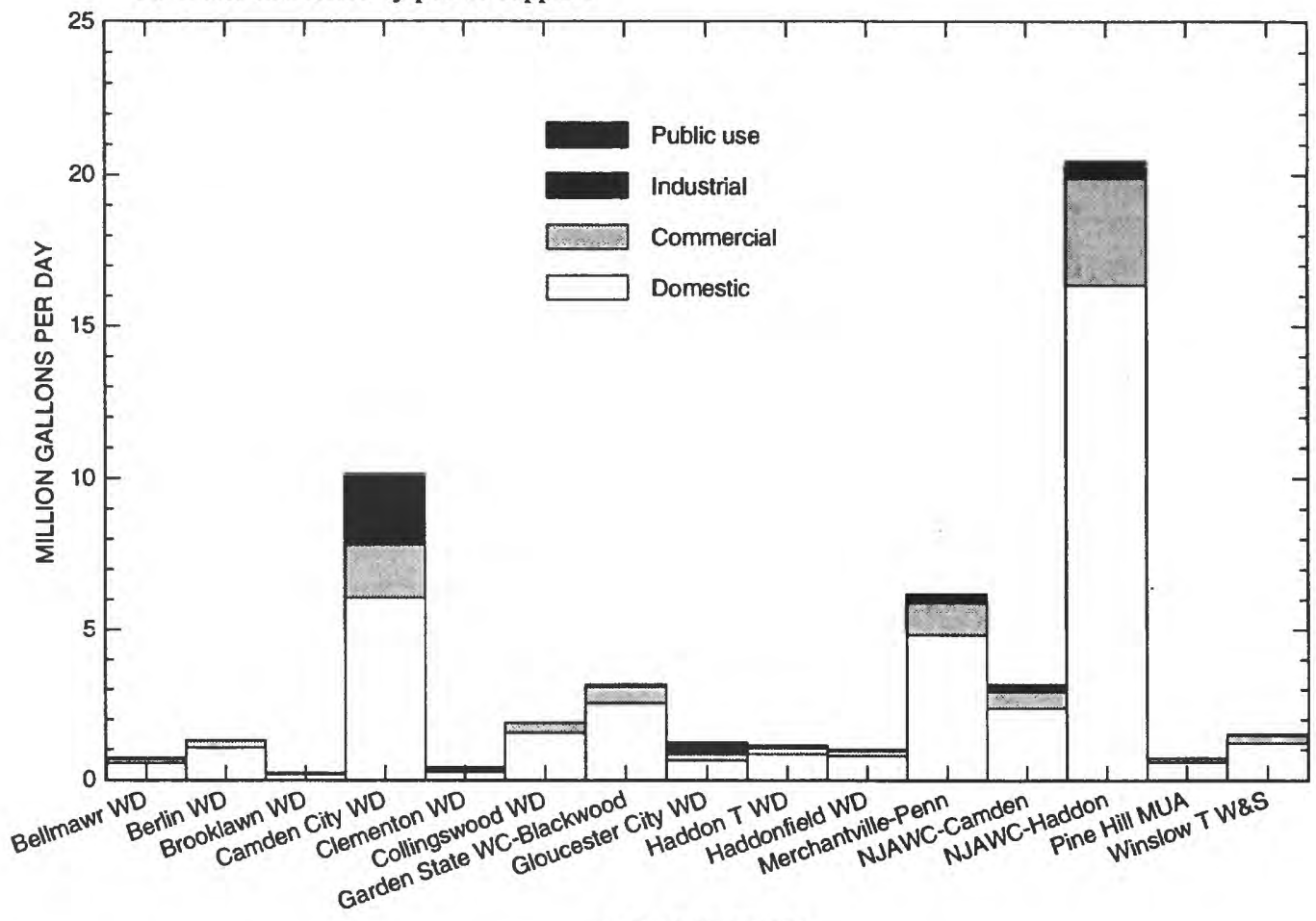

PUBLIC SUPPLIER

B. Consumptive use of publicly supplied water users

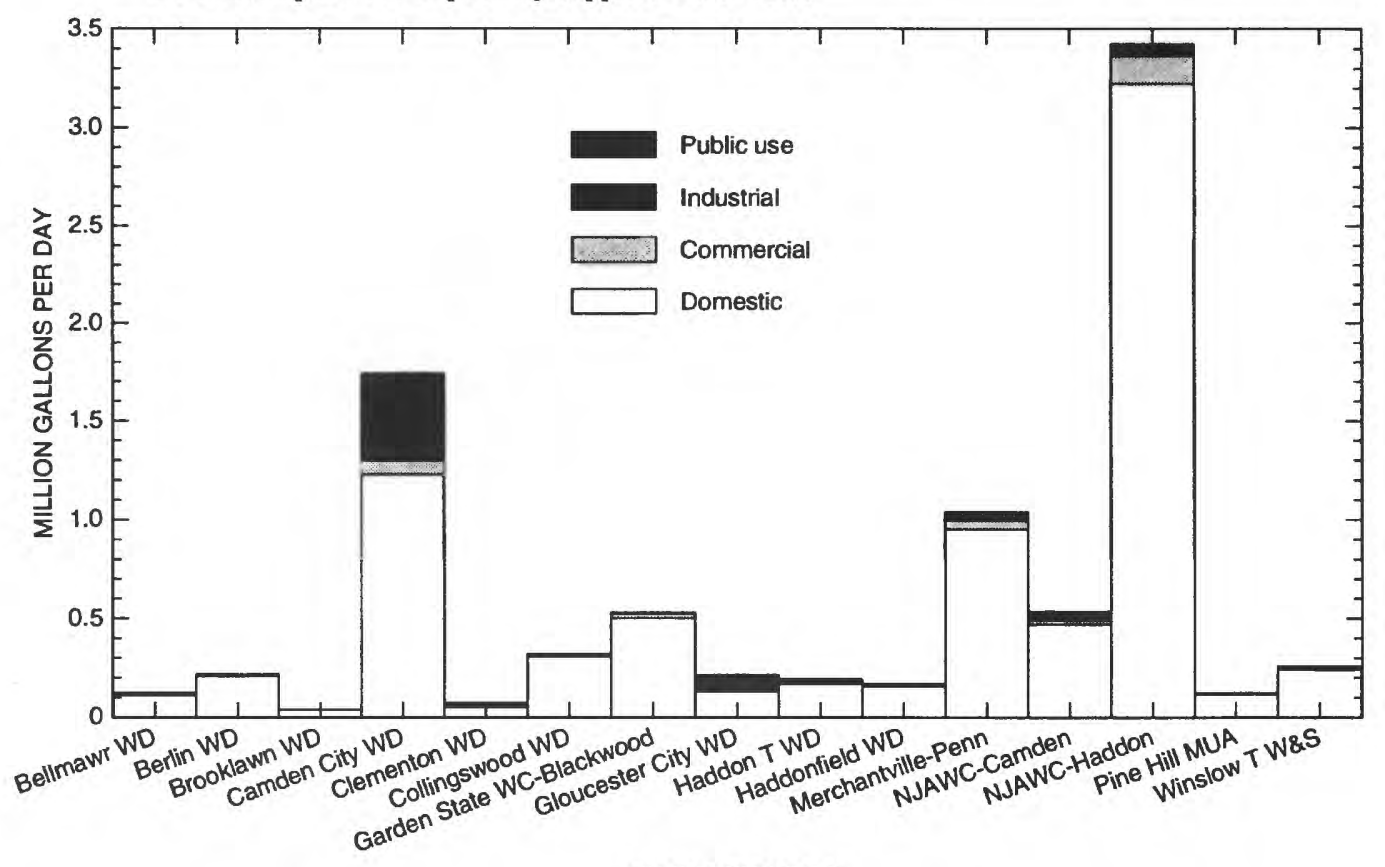

PUBLIC SUPPLIER

Figure 5. Water deliveries and consumptive use in Camden County, New Jersey, by category of use, 1991. (MUA, Municipal Utilities Authority; NJWAC, New Jersey American Water Company; Merchantville-Penn., Merchantville-Pennsauken Water Commission; T, Township; WC, Water Company; WD, Water Department, W \& S, Water and Sewer Department) 


\section{Table 5. Water deliveries and water distribution in Camden County, New Jersey, by public supplier and use, 1991}

[Figures may not add to totals because of independent rounding. Data on file at the New Jersey Department of Environmental Protection, Trenton, N.J.; all withdrawals in million gallons per day; --, no values reported; Merchantville-Penn, Merchantville-Pennsauken Water Commission; NJAWC, New Jersey-American Water Company; MUA, Municipal Utilities Authority; T, Township; WC, Water Company; WD, Water Department; W\&S, Water and Sewer Department]

\begin{tabular}{|c|c|c|c|c|c|}
\hline Public supplier & $\begin{array}{l}\text { Reported } \\
\text { withdrawals }\end{array}$ & $\begin{array}{l}\text { Distributed water }{ }^{1,2} \\
\text { (Metered water, public } \\
\text { use, and bulk sales) }\end{array}$ & Domestic $^{3}$ & Commercial $^{4}$ & Industrial $^{4}$ \\
\hline Bellmawr WD & 1.07 & 0.79 & 0.61 & 0.13 & 0.02 \\
\hline Berlin WD & 1.42 & 1.41 & 1.16 & .23 & .03 \\
\hline Brooklawn WD & .25 & .25 & .21 & .04 & -- \\
\hline Camden City WD & 16.60 & 10.92 & 6.82 & 1.75 & .22 \\
\hline Clementon WD & .65 & .45 & .28 & .07 & .01 \\
\hline Collingswood WD & 2.24 & 2.04 & 1.70 & .33 & -- \\
\hline Garden State WC--Blackwood & 3.62 & 3.41 & 2.79 & .55 & .07 \\
\hline Gloucester City WD & 1.42 & 1.33 & .73 & .21 & .03 \\
\hline Haddon T WD & 1.47 & 1.23 & .94 & .20 & .02 \\
\hline Haddonfield WD & 1.21 & 1.08 & .87 & .17 & -- \\
\hline Merchantville-Penn & 6.85 & 6.66 & 5.29 & 1.07 & .13 \\
\hline NJWAC--Camden & 3.47 & 3.42 & 2.61 & .55 & .07 \\
\hline NJWAC--Haddon & 23.82 & 22.00 & 17.91 & 3.52 & .44 \\
\hline Pine Hill MUA & .85 & .78 & .65 & .12 & -- \\
\hline Winslow T W\&S & 1.83 & 1.64 & 1.34 & .26 & - \\
\hline Total & 67 & 57 & 44 & 9 & 1 \\
\hline Percentage of all withdrawals & 100 & 85 & 66 & 13 & 2 \\
\hline
\end{tabular}

${ }^{1}$ Data from Water Utilization Reports and Water Conservation Plans from the New Jersey Department of Environmental Protection.

${ }^{2}$ Does not include lost or unaccounted-for water.

${ }^{3}$ Domestic deliveries estimated by subtracting the sum of the commercial and industrial deliveries from the total for metered water.

${ }^{4}$ Water-use coefficient multiplied by the distributed water. 


\section{Estimates Based on Public-Supply Withdrawal Data}

Per capita use was estimated on the basis of (1) total public-supply withdrawals and (2) estimated domestic deliveries. Data on monthly withdrawals by public suppliers were compiled to identify the month with the lowest daily average withdrawals, which indicated chiefly indoor water use, and the month with the greatest daily average withdrawals, which indicated the greatest outdoor use. Per capita use was estimated on the basis of annual and monthly public-supply withdrawals. Withdrawals for public supply in Camden County totaled $67 \mathrm{Mgal} / \mathrm{d}$ in 1991 (per capita use, $141 \mathrm{gal} / \mathrm{d}$ ) (fig. 6). The lowest monthly public-supply withdrawals in the county were in February, $53 \mathrm{Mgal} / \mathrm{d}$ (per capita use, $111 \mathrm{gal} / \mathrm{d}$ ). The highest average monthly public-supply withdrawals were in July, $77 \mathrm{Mgal} / \mathrm{d}$ (per capita use, $162 \mathrm{gal} / \mathrm{d}$ ). Per capita use in July (peak water use) averaged about $51 \mathrm{gal} / \mathrm{d}$ more than per capita use in February (fig. 6).

Domestic deliveries were estimated for each public supplier on the basis of coefficients and calculations (table 5). Domestic deliveries in February and July were estimated on the basis of the percentage of total domestic withdrawals (66 percent). Domestic deliveries in 1991 totaled $44 \mathrm{Mgal} / \mathrm{d}$ (per capita use $92 \mathrm{gal} / \mathrm{d}$ ) (table 5). The lowest average daily domestic deliveries were in February and were estimated to be $36 \mathrm{Mgal} / \mathrm{d}$ (per capita use $76 \mathrm{gal} / \mathrm{d}$ ). In July, domestic deliveries were estimated to be $51 \mathrm{Mgal} / \mathrm{d}$ (per capita use $107 \mathrm{gal} / \mathrm{d}$ ). Peak water use in July averaged about $31 \mathrm{gal} / \mathrm{d}$ per person more than per capita use in February (fig. 6); most of the increased use in July can be attributed to outdoor water uses.

\section{Estimates Reported by Public Suppliers}

Another method of estimating per capita water use is to rely on data reported by public suppliers. The average daily per capita use reported during 1991 by public suppliers in Camden County ranged from $62 \mathrm{gal} / \mathrm{d}$ (Gloucester City Water Department) to $116 \mathrm{gal} / \mathrm{d}$ (MerchantvillePennsauken Water Commission) (fig. 7a; table 6). Values reported by public suppliers were reported to be calculated from data on domestic deliveries, not total water withdrawals of the system. Some of the values shown in table 6 may represent a per capita calculation based on total water withdrawals or inaccurate population estimates (fig. 7b); as a result, this calculation could artificially increase or decrease the per capita value. A comparison with the per capita use calculated from estimated domestic deliveries shows the differences (table 6).

\section{Estimates Reported Nationally and in Other Studies in New Jersey}

Per capita use in Camden County was estimated to be within the range of the average per capita use in the United States (table 7). According to national studies, the daily water use for an urban household of four persons residing in a single-family dwelling unit was estimated to range from $309 \mathrm{gal}$ (per capita use of $77 \mathrm{gal} / \mathrm{d}$ ) to $494 \mathrm{gal}$ (per capita use of $124 \mathrm{gal} / \mathrm{d}$ ). Estimated indoor water use was about $209 \mathrm{gal} / \mathrm{d}$ (per capita use of $52 \mathrm{gal} / \mathrm{d}$ ) to $314 \mathrm{gal} / \mathrm{d}$ (per capita use of $79 \mathrm{gal} / \mathrm{d}$ ) and outdoor water use ranged from $100 \mathrm{gal} / \mathrm{d}$ to $180 \mathrm{gal} / \mathrm{d}$ (Sanders and Thurow, 1982; van der Leeden and others, 1990; American Water Works Association, 1992; Vern Achtermann, American Water Works Association, written commun., 1995). Generally, residents of multifamily housing units have minimal outdoor water use; consequently, their use of water is primarily for household 
A. Domestic and other deliveries

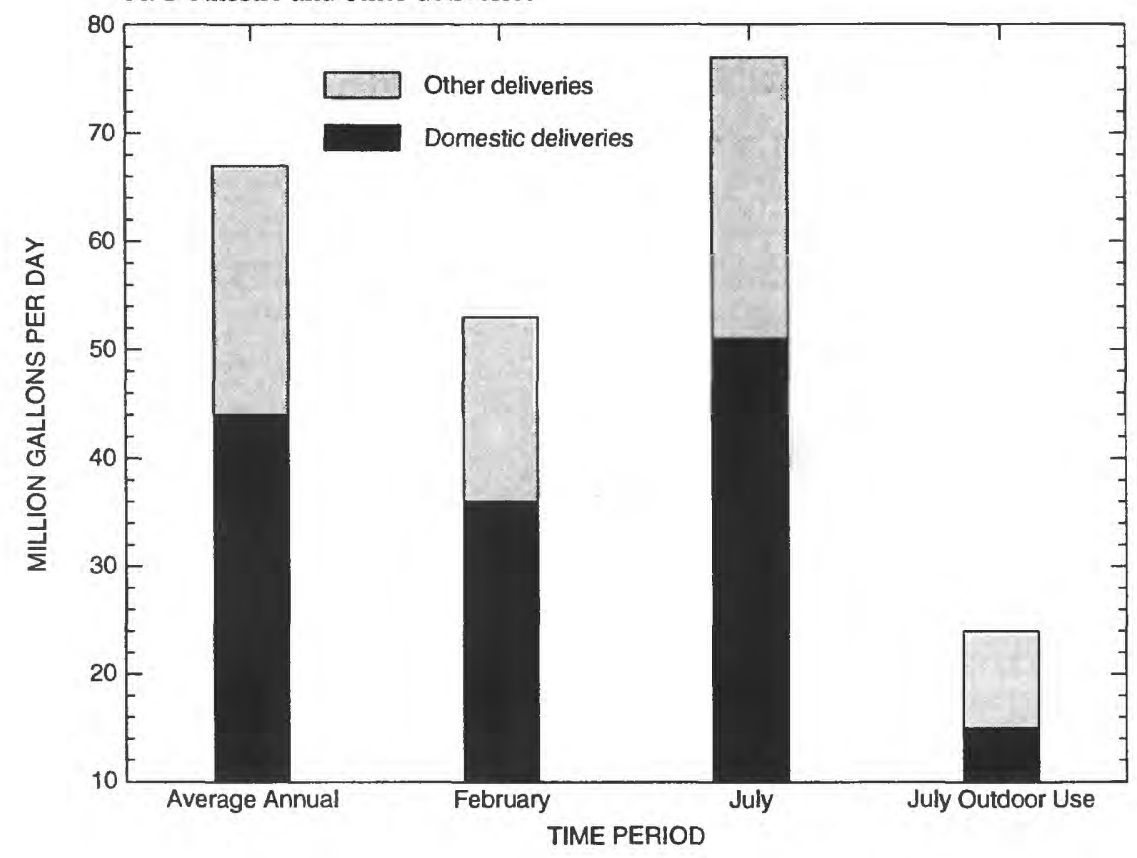

B. Per capita use

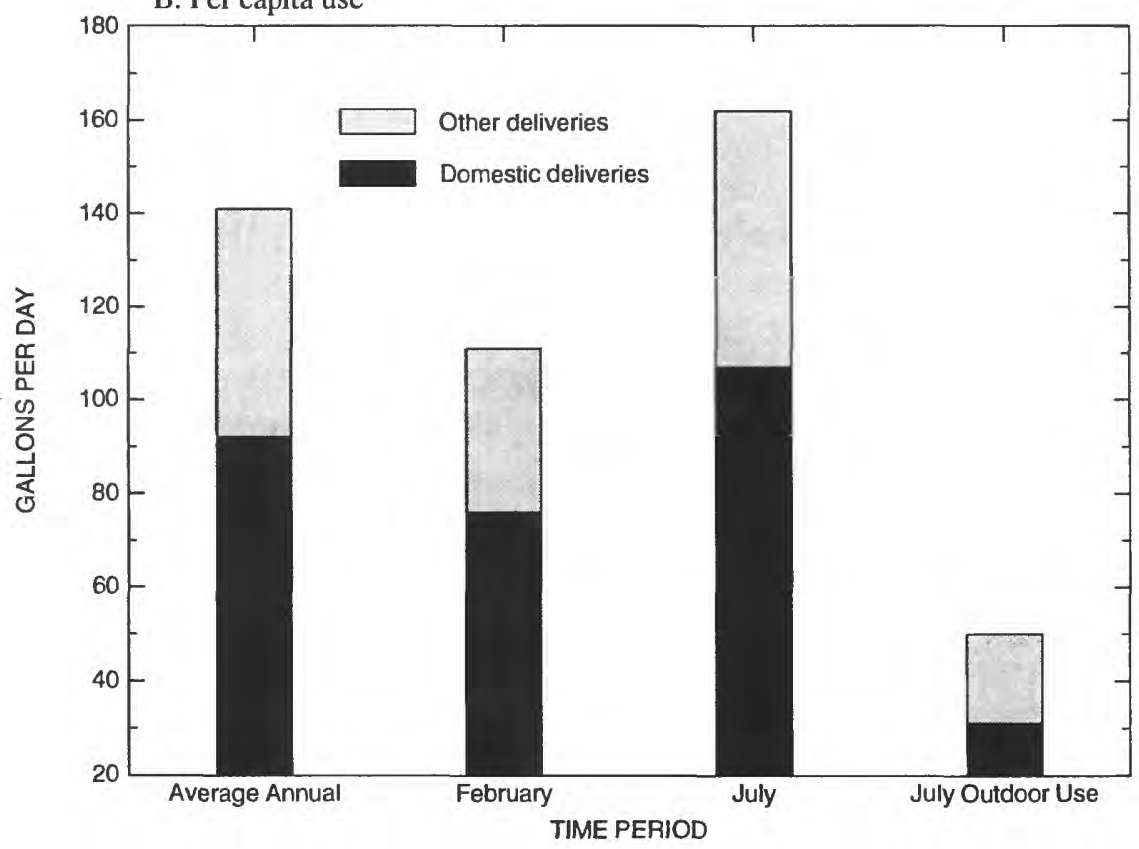

Figure 6. Domestic and other delivieres, and per capita use in Camden County, New Jersey, by time period, 1991. 


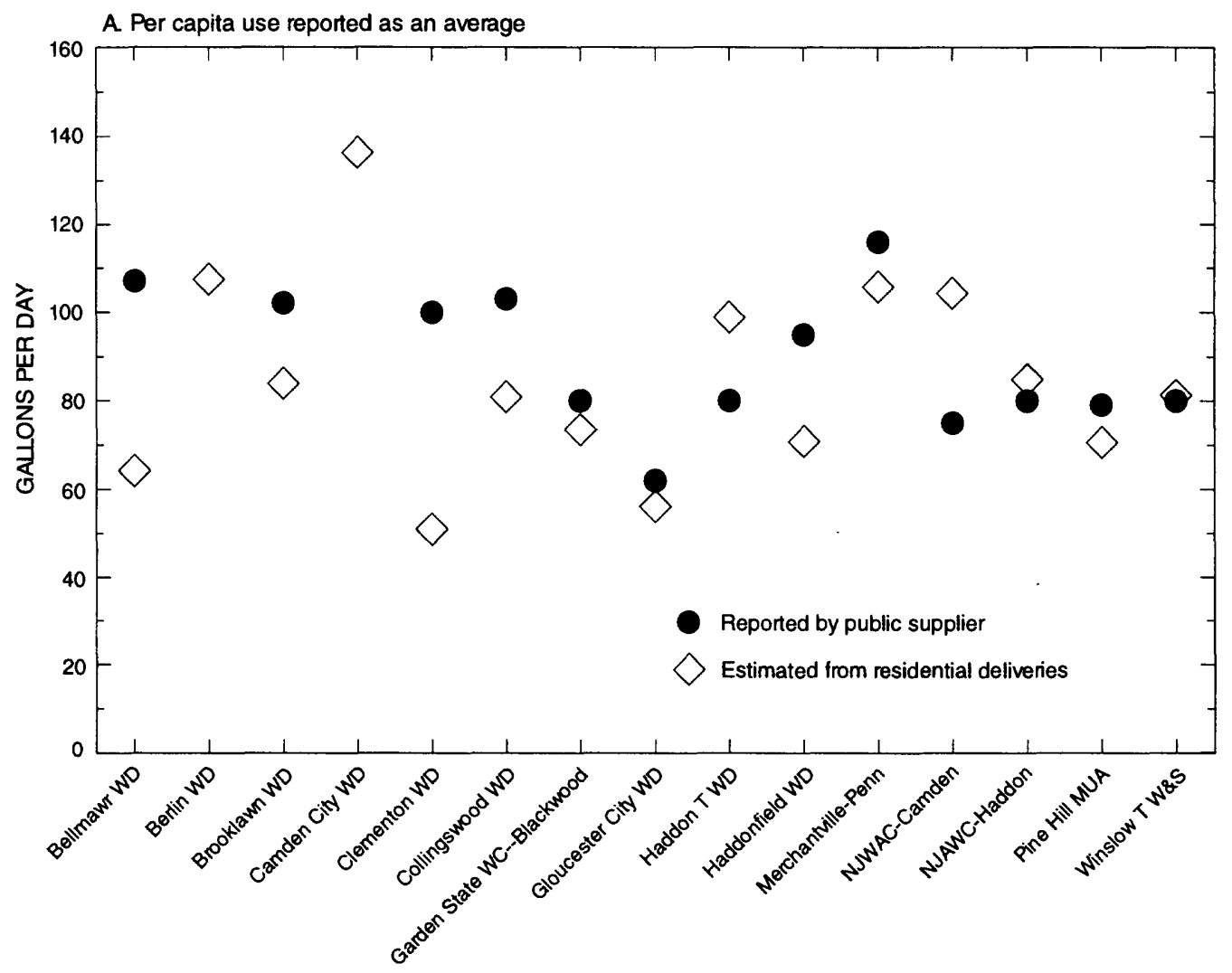

PUBUC SUPPUER

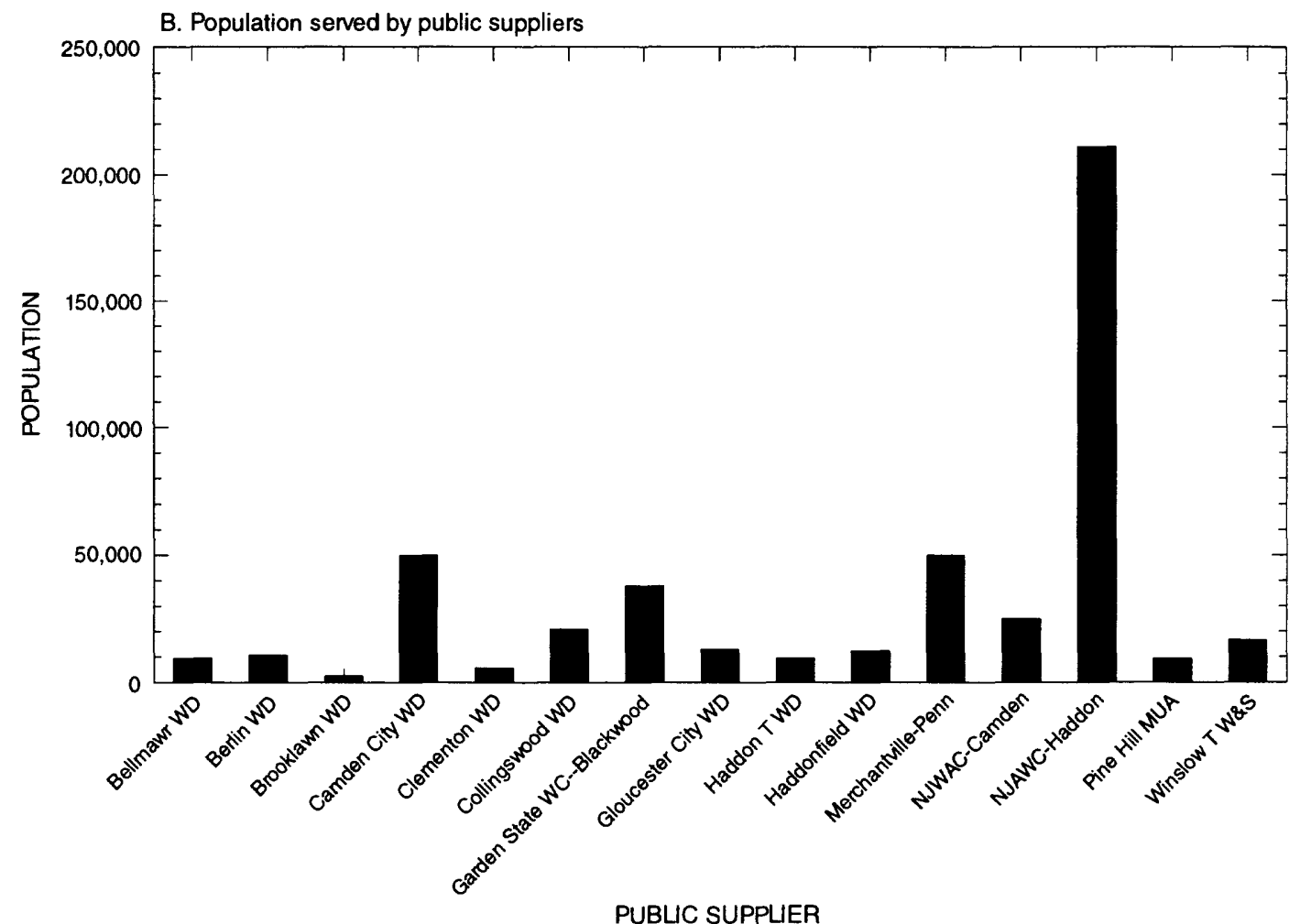

Figure 7. Per capita use and population served in Camden County, New Jersey, reported by public supplier, 1991. (Data on file at the New Jersey Department of Environmental Protection, Trenton, New Jersey; MUA, Municipal Utilities Authority; NJAWC, New Jersey-American Water Company; Merchantville-Penn, MerchantvillePennsauken Water Commission; T, Township; WC, Water Company; WD, Water Department; W\&S, Water and Sewer Department) 
Table 6. Per capita water use in Camden County, New Jersey, by public supplier, reported by public supplier and estimated from total withdrawals, metered deliveries, and domestic deliveries, 1991

[Modified from data on file at the New Jersey Department of Environmental Protection, Trenton, N.J., and U.S. Bureau of the Census, 1992; per capita in gallons per day; --, not reported; MUA, Municipal Utilities Authority; NJAWC, New Jersey-American Water Company; Merchantville-Penn, Merchantville-Pennsauken Water Commission; T, Township; WC, Water Company; WD, Water Department; W\&S, Water and Sewer Department]

\begin{tabular}{|c|c|c|c|c|c|}
\hline \multirow[b]{2}{*}{ Public supplier } & \multicolumn{4}{|c|}{ Average per capita } & \multirow[b]{2}{*}{$\begin{array}{l}\text { Population } \\
\text { served }^{1}\end{array}$} \\
\hline & $\begin{array}{l}\text { Reported by } \\
\text { public supplier }\end{array}$ & $\begin{array}{l}\text { Estimated } \\
\text { from total } \\
\text { withdrawal }\end{array}$ & $\begin{array}{l}\text { Estimated } \\
\text { from metered } \\
\text { deliveries }^{2}\end{array}$ & $\begin{array}{l}\text { Estimated } \\
\text { from } \\
\text { domestic } \\
\text { deliveries }\end{array}$ & \\
\hline Bellmawr WD & 107 & 113 & 79 & 64 & 9,500 \\
\hline Berlin WD & -- & 131 & 131 & 107 & ${ }^{3} 10,800$ \\
\hline Brooklawn WD & 102 & 100 & 100 & 84 & 2,500 \\
\hline Camden City WD & -- & 332 & 176 & 136 & 50,000 \\
\hline Clementon WD & 100 & 118 & 65 & 51 & 5,500 \\
\hline Collingswood WD & 103 & 107 & 97 & 81 & 21,000 \\
\hline Garden State WC-Blackwood & 80 & 95 & 90 & 73 & 38,000 \\
\hline Gloucester City WD & 62 & 109 & 75 & 56 & 13,000 \\
\hline Haddon T WD & 80 & 155 & 122 & 99 & 9,500 \\
\hline Haddonfield WD & 95 & 98 & 85 & 71 & 12,300 \\
\hline Merchantville-Penn & 116 & 137 & 130 & 106 & 50,000 \\
\hline NJWAC- Camden & 75 & 139 & 130 & 104 & 25,000 \\
\hline NJWAC- Haddon & 80 & 113 & 100 & 85 & 211,000 \\
\hline Pine Hill MUA & 79 & 92 & 84 & 71 & 9,200 \\
\hline Winslow T W\&S & 80 & 111 & 92 & 81 & ${ }^{3} 16,500$ \\
\hline $\begin{array}{l}\text { Average per capita use and } \\
\text { total population }\end{array}$ & 89 & 130 & 104 & 85 & 483,800 \\
\hline $\begin{array}{l}\text { Camden County only; average } \\
\text { per capita use and total } \\
\text { population }{ }^{3}\end{array}$ & -- & 141 & 111 & 92 & 476,400 \\
\hline
\end{tabular}


Table 7. Estimated urban water use in Camden County, New Jersey, for a family of four

[Figures may not add to totals because of independent rounding; household use and per capita use in gallons per day. Modified from Sanders and Thurow, 1982; van der Leeden, 1990; Vern Achtermann, American Water Works Association, written commun., 1995]

\begin{tabular}{|c|c|c|}
\hline Type and frequency of use & Household use & Per capita use \\
\hline \multicolumn{3}{|c|}{ Single-family housing units } \\
\hline Drinking and kitchen use & $8-40$ & $2-10$ \\
\hline Dishwasher (I load per day) & $5-8$ & $1-2$ \\
\hline Toilet (16 flushes per day) & $96-108$ & $24-27$ \\
\hline Bathing (4 baths or showers per day) & $56-80$ & $14-20$ \\
\hline Laundering (6 loads per week) & $34-68$ & $8-17$ \\
\hline $\begin{array}{l}\text { Automobile washing (2 car washes per } \\
\text { month) }\end{array}$ & 10 & 2 \\
\hline $\begin{array}{l}\text { Lawn watering and swimming pools } \\
\quad(180 \text { hours per year) }\end{array}$ & $100-180$ & $25-45$ \\
\hline Total for single-family units & $309-494$ & $77-124$ \\
\hline \multicolumn{3}{|c|}{ Multifamily housing units } \\
\hline $\begin{array}{l}\text { Drinking and kitchen use, dishwasher, } \\
\text { toilet, bathing, and laundering } \\
\text { (Does not include automobile } \\
\text { washing, lawn watering, and } \\
\text { swimming pools) }\end{array}$ & $199-304$ & $50-76$ \\
\hline
\end{tabular}


purposes and ranges from $199 \mathrm{gal} / \mathrm{d}$ to $304 \mathrm{gal} / \mathrm{d}$ (per capita use of $50 \mathrm{gal} / \mathrm{d}$ to $76 \mathrm{gal} / \mathrm{d}$ ) (table 7). The per capita use of residential users in New Jersey reported in previous studies ranged from $75 \mathrm{gal} / \mathrm{d}$ to $100 \mathrm{gal} / \mathrm{d}$ (Merend, 1989; Saarela, 1992; Solley and others, 1993; Nawyn and Clawges, 1995).

\section{Estimates for Domestic Use}

In Camden County, the use of water by residents of single-family housing units that have their own source of water is similar to the use of water by residents of single-family housing units in nearby publicly supplied communities. Environmental variables such as temperature and rainfall show little, if any, variation between areas of self-supplied and publicly supplied water users. In some suburban areas, residential neighborhoods are composed of publicly supplied and self-supplied households. The size of households and incomes of publicly supplied and selfsupplied single-family housing units are also similar.

The variable that differentiates publicly supplied and self-supplied water users is the price of water. Although an electrical cost is associated with maintaining a domestic-supply system, the price of water for self-supplied residents of single-family housing units is minimal. Generally, self-supplied residents can use water for lawns and gardens, swimming pools, and other outdoor uses at a lower cost than can residents of single-family housing units in nearby publicly supplied areas.

Another factor that can affect water use is the age of the housing unit and the type of water fixtures, such as toilets. Since the early 1980's, water-conserving fixtures have been installed in all new housing units, and, more recently, water-conserving toilets are the only type of replacement toilets available. When the natural replacement of existing water fixtures in older publicly supplied housing units is completed, the water use of publicly supplied and self-supplied water users may become more clearly defined.

In this report, per capita use of self-supplied domestic users was estimated to be $84 \mathrm{gal} / \mathrm{d}$. Most of these self-supplied users in Camden County resided in Winslow and Waterford Townships (table 1) in housing units constructed after 1980; these housing units have waterconserving water fixtures (U.S. Bureau of the Census, 1992). The per capita use estimated for self-supplied users is similar to the per capita use reported by public suppliers in adjacent communities (table 6).

\section{Losses From the Water Distribution System of Public Suppliers}

In 1991, about $9 \mathrm{Mgal} / \mathrm{d}$ of public-supply withdrawals in Camden County were not accounted for as metered deliveries, public water use, or bulk deliveries to other public suppliers (table 4). About 1 percent of public-supply withdrawals were lost as untreated water that was used to backwash pumping equipment and other well-maintenance operations. Other distribution losses were water leaks, improperly registered meters, unauthorized use of fire hydrants, and illegal water connections. 
Data on the volume of water that is lost or unaccounted for in the water distribution system in Camden County were compiled from the NJDEP files or estimated from coefficients developed from data on other public suppliers. Most public suppliers submitted a "Water Utilization Report" that indicated the volume of (1) all withdrawals, (2) treated water (available for delivery), (3) metered deliveries, (4) unmetered water deliveries (public use water), (5) bulk sales to other public suppliers, and (6) lost or unaccounted-for water (table 4).

The unaccounted-for water of all public suppliers in Camden County represented 12 percent of public-supply withdrawals. In the USEPA Region II (includes New Jersey) and Region III (includes Pennsylvania), the average unaccounted-for water in public water-supply systems was 14 percent of total withdrawals (van der Leeden and others, 1990) (table 4).

For public suppliers who did not submit a report, unaccounted-for water was assumed to be 10 percent of water deliveries. This percentage represents the average water distribution losses among the public suppliers in Camden County when the unusually high losses of the Camden City Water Department were excluded from the calculation (table 4).

\section{Consumptive Water Use}

Consumptive use is the water that is evaporated, transpired, or incorporated into products or crops (Solley and others, 1993). Consumptive use in 1991 in Camden County was estimated to be about $9 \mathrm{Mgal} / \mathrm{d}$ for public-supply withdrawals and $3 \mathrm{Mgal} / \mathrm{d}$ for self-supplied withdrawals. Consumptive-use coefficients that were developed by the USGS and others were used to estimate the volume of water consumed or otherwise used in Camden County (L.D. Patrick and others, U.S. Geological Survey, written commun., 1990; Solley and others, 1993).

\section{Domestic}

Public-supplied domestic users consumed about $8 \mathrm{Mgal} / \mathrm{d}$ (table 8). Most of the water entering residences will return as effluent to the local municipal wastewater treatment plant or onsite wastewater disposal system. Although the consumptive-use coefficient for self-supplied domestic users $(0.20)$ is about the same as that for publicly supplied residents $(0.18)$, self-supplied domestic users typically have more outdoor water use, such as lawn watering and gardening, than many publicly supplied users who may use water primarily for indoor activities and whose outdoor water use is limited (table 8 ). Consumptive use of self supplied domestic users was estimated to be less than $1 \mathrm{Mgal} / \mathrm{d}$ (table 8).

\section{Commercial}

The lowest consumptive use coefficient (0.04) among the water-use categories was estimated for commercial users. About 4 out of every 100 gal of water delivered to commercial users or withdrawn by commercial self-supplied users is consumptive use. Consumptive use of publicly supplied and self-supplied commercial users was estimated to total less than $1 \mathrm{Mgal} / \mathrm{d}$ (table 8). 
Table 8. Consumptive use of public-supply and self-supply users in Camden County, New Jersey, by category of use, 1991

[Figures may not add to totals because of independent rounding. Values for distributed water, withdrawals, and consumptive use in million gallons per day; NA, not applicable]

\begin{tabular}{|c|c|c|c|}
\hline Category of use & Coefficient & $\begin{array}{c}\text { Distributed } \\
\text { water/ } \\
\text { withdrawals }{ }^{1}\end{array}$ & $\begin{array}{c}\text { Consumptive } \\
\text { use }\end{array}$ \\
\hline \multicolumn{4}{|c|}{ Public-supply deliveries } \\
\hline Domestic & 0.18 & 44 & 8 \\
\hline Commercial & .04 & 9 & $<1$ \\
\hline Industrial & .08 & 1 & $<1$ \\
\hline Public water use & .20 & 3 & 1 \\
\hline Total & NA & 57 & 9 \\
\hline \multicolumn{4}{|c|}{ Self-supply withdrawals } \\
\hline Domestic & .20 & 2 & $<1$ \\
\hline Commerical & .04 & NA & $<1$ \\
\hline Industrial & .08 & 4 & $<1$ \\
\hline Irrigation & .90 & 2 & 2 \\
\hline Mining & .08 & 1 & $<1$ \\
\hline Total & NA & 10 & 3 \\
\hline County total & NA & 67 & 12 \\
\hline
\end{tabular}

${ }^{1}$ Does not include distribution losses or bulk sales to other public suppliers. 


\section{Industrial, Irrigation, and Mining}

The consumptive-use coefficient for industrial use is estimated to be 0.08 . More than onehalf of the gross water (the sum of water intake plus water recirculated and reused without regard to evaporation) used by industrial facilities is recycled within the facility (U.S. Bureau of the Census, 1983b). The recycled water is commonly used for cooling industrial processes and lawn watering (Ploeser and others, 1992).

Data on industrial water use in 1991 in Camden County were available for only a few facilities; however, data on the total use of water by industries in New Jersey are available for 1983. During that year, cooling and condensing (69 percent), production or process water ( 25 percent), sanitary services ( 2 percent), and boiler feed ( 3 percent) were the chief uses of water in industrial facilities in the State (U.S. Bureau of the Census, 1983b).

The consumptive use of publicly or self-supplied industrial water users are about the same regardless of the source of supply. Mining water use is chiefly self-supplied, and the consumptiveuse coefficient is the same as that for industrial water use (0.08). Water used for irrigation in Camden County is assumed to be almost entirely consumptive (0.90). Less than $2 \mathrm{Mgal} / \mathrm{d}$ of all industrial, irrigation, and mining water use in Camden County was consumptive use; irrigation water use of about $1 \mathrm{Mgal} / \mathrm{d}$ was the chief consumptive use among self-supplied water users.

\section{Public Water}

It is difficult to determine how water is used in municipal facilities, and, consequently, how much public water use is consumptive. The consumptive-use coefficient of water for schools and municipal buildings (food services and sanitary services) was assumed to be 0.04 , the same consumptive-use coefficient as commercial use. The consumptive-use coefficient of water for lawn watering is estimated to be 0.90 ; however, lawn watering accounts for a small volume of public water use. The consumptive use of water used for street cleaning and firefighting can vary widely. Given the uncertainty of public water use, the water use coefficient was estimated to be 0.20 to account for the wide variety of consumptive use of this water.

\section{Wastewater Discharge}

The volume of wastewater discharged by municipal wastewater treatment facilities in Camden County in 1991 (fig. 8) was $58 \mathrm{Mgal} / \mathrm{d}$ (fig. 9; table 9). An estimated $55 \mathrm{Mgal} / \mathrm{d}$ of publicly supplied water was returned to streams through the wastewater treatment plants. (table 10). Inflow from storm sewers and ground water, or additional water from public water use such as firefighting, was estimated to be about $3 \mathrm{Mgal} / \mathrm{d}$ (fig. 9; table 10).

Discharges by wastewater treatment plants in Camden County during 1990-91 were compiled from the USEPA Permit Compliance System. The number of wastewater treatment facilities in the county decreased from 21 in 1990 to 15 in 1991 when the regional wastewater facility (Camden County) (fig. 8) increased its share of the wasteloads in the county from 63 percent in 1990 to 82 percent in 1991 (table 9). 


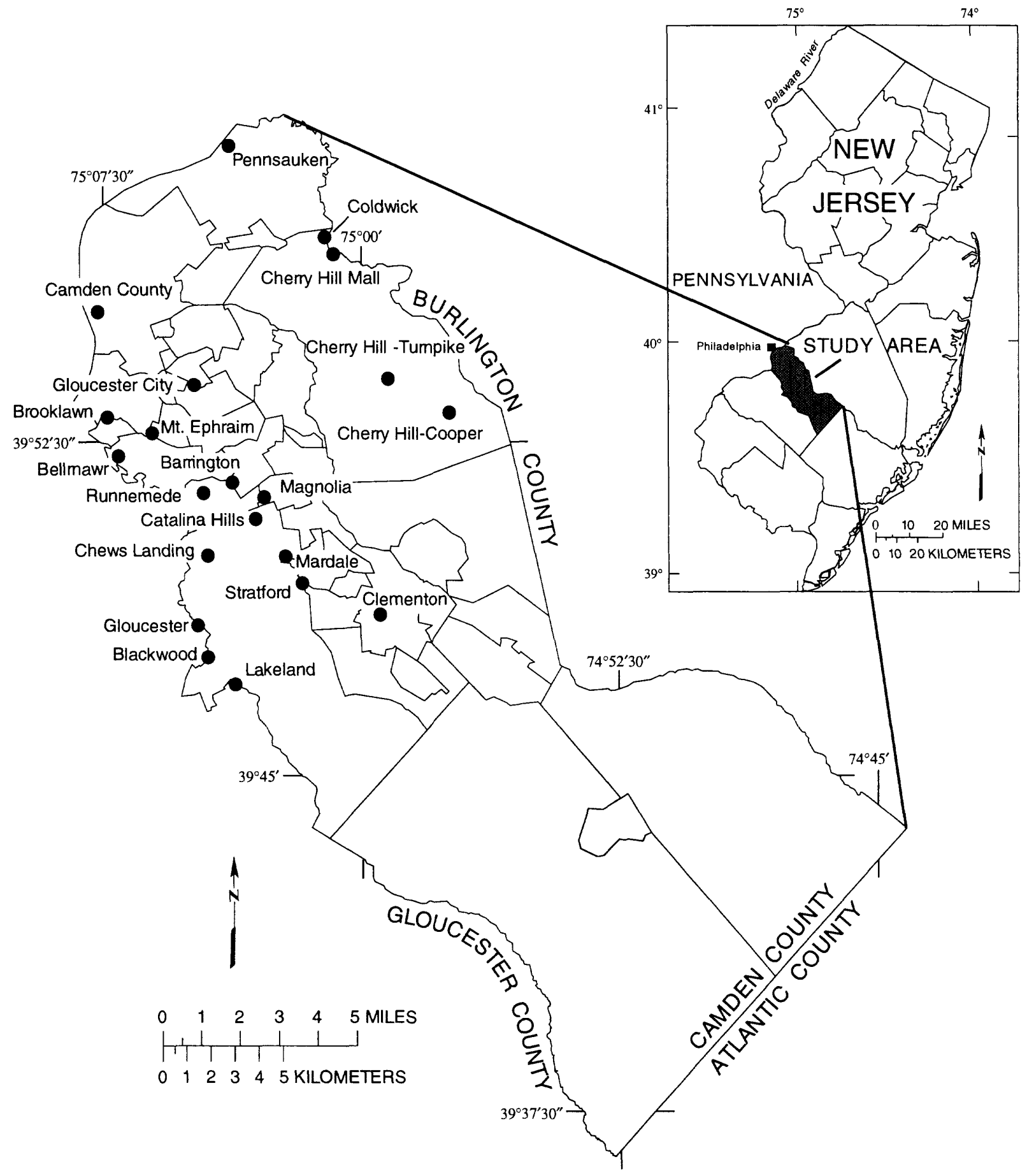

Figure 8. Municipal wastewater treatment facilities in Camden County, New Jersey, 1990-91. (Data from Permit Compliance System data base, U.S. Environmental Protection Agency, Washington, D.C.) 


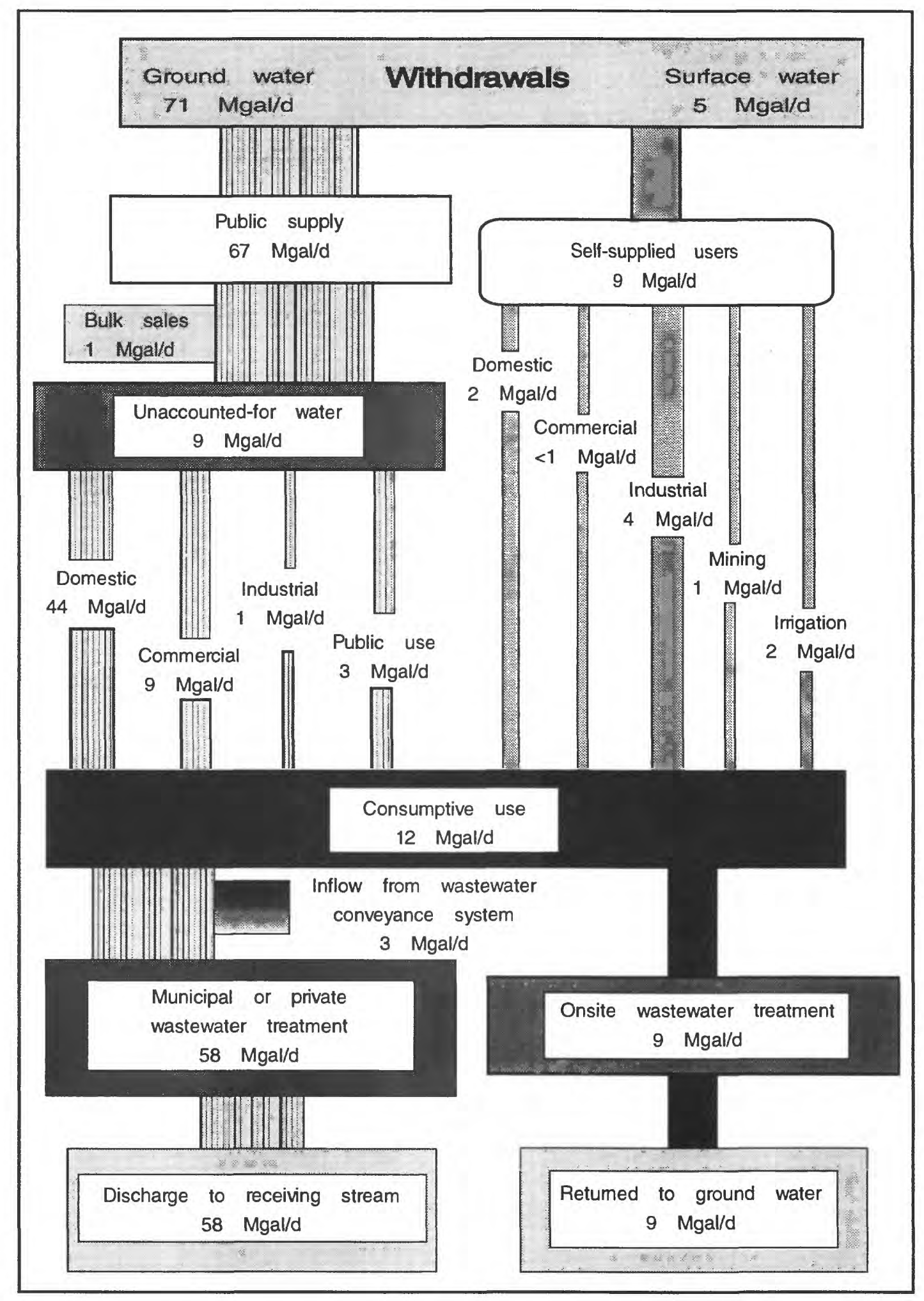

Figure 9. Generalized summary of water use in Camden County, New Jersey, 1991. (Withdrawals in million gallons per day, Mgal/d) 
Table 9. Municipal wastewater-treatment facilities and wastewater discharges in Camden County, New Jersey, 1990-91

[Figures may not add to totals because of independent rounding. All values in million gallons per day. Data from Permit Compliance System data base on file, U.S. Environmental Protection Agency, Washington, D.C.]

\begin{tabular}{|c|c|c|c|}
\hline \multirow[b]{2}{*}{ Facility } & \multirow[b]{2}{*}{ NJDES ID ${ }^{1}$} & \multicolumn{2}{|c|}{ Year } \\
\hline & & 1990 & 1991 \\
\hline Barrington & NJ0026875 & 0.63 & 0.68 \\
\hline Bellmawr & NJ0026743 & 1.43 & 1.78 \\
\hline Berlin & NJ0026972 & .62 & Closed \\
\hline Blackwood & NJ0026476 &. .83 & .71 \\
\hline Brooklawn & NJ0022748 & .18 & .15 \\
\hline Camden County & NJ0026182 & 37.71 & 47.41 \\
\hline Catalina Hills & NJ0026492 & .11 & .11 \\
\hline Cherry Hill-Cooper & NJ002504 & .64 & Closed \\
\hline Cherry Hill-Turnpike & NJ002505 & 1.28 & Closed \\
\hline Cherry Hill-Mall & NJ002508 & .53 & .44 \\
\hline Chews Landing & NJ002646 & 3.58 & 2.73 \\
\hline Clementon & NJ002032 & .68 & .62 \\
\hline Coldwick & NJ002512 & .13 & .12 \\
\hline Gloucester City & NJ002662 & 1.89 & Closed \\
\hline Lakeland & NJ002984 & .12 & .15 \\
\hline Magnolia & NJ002143 & .71 & .49 \\
\hline Mardale & NJ002648 & .12 & .13 \\
\hline Mt. Ephraim & NJ002381 & 4.39 & Closed \\
\hline Pennsauken & NJ002534 & 2.21 & 1.88 \\
\hline Runnemede & NJ002685 & .88 & Closed \\
\hline Stratford & NJ002262 & .86 & .76 \\
\hline County total & & 60 & 58 \\
\hline
\end{tabular}

\footnotetext{
${ }^{1}$ New Jersey Discharge Elimination System Identification number.
} 
Table 10. Withdrawals of ground water and surface water, consumptive and nonconsumptive use, unaccounted-for water, and wastewater treatment and disposal in Camden County, New Jersey, 1991

[Figures may not add to totals because of independent rounding. All values in million gallons per day; --, no reported values]

\begin{tabular}{|c|c|c|c|c|c|}
\hline \multirow[b]{2}{*}{ Category of use } & \multirow{2}{*}{$\begin{array}{c}\text { Distribution/ withdrawal/ } \\
\text { discharge }\end{array}$} & \multirow{2}{*}{$\begin{array}{l}\text { Consumptive } \\
\text { water use }\end{array}$} & \multirow{2}{*}{$\begin{array}{l}\text { Nonconsumptive } \\
\text { water use }\end{array}$} & \multicolumn{2}{|c|}{ Wastewater treatment and disposal } \\
\hline & & & & Municipal & Onsite \\
\hline \multicolumn{6}{|c|}{ Public Supply } \\
\hline Domestic $^{1}$ & 44 & 8 & 36 & 34 & 2 \\
\hline Commercial $^{1}$ & 9 & $<1$ & 9 & 9 & $<1$ \\
\hline Industrial $^{1}$ & 1 & $<1$ & 1 & 1 & $<1$ \\
\hline Public Use $^{1}$ & 3 & 1 & 2 & 2 & $<1$ \\
\hline Bulk Sales ${ }^{1}$ & 1 & $<1$ & $<1$ & $<1$ & $<1$ \\
\hline Unaccounted-for water $^{1}$ & 9 & -- & 9 & 9 & $<1$ \\
\hline Total $^{1}$ & 67 & 9 & 57 & ${ }^{4} 55$ & 3 \\
\hline \multicolumn{6}{|c|}{ Non-public Supply } \\
\hline Domestic $^{2}$ & 2 & $<1$ & 2 & - & 2 \\
\hline Commercial $^{3}$ & $<1$ & $<1$ & $<1$ & $<1$ & $<1$ \\
\hline Industrial $^{3}$ & 4 & $<1$ & 4 & $<1$ & 4 \\
\hline Irrigation $^{2}$ & 2 & 2 & $<1$ & & -- \\
\hline Mining $^{3}$ & 1 & $<1$ & 1 & -- & 1 \\
\hline Total $^{2,3}$ & 9 & 3 & 7 & $<1$ & 7 \\
\hline County ${ }^{1-4}$ & 76 & 12 & ${ }^{4} 64$ & ${ }^{4} 55$ & 10 \\
\hline Percent & 100 & 16 & 84 & 72 & 13 \\
\hline
\end{tabular}

Wastewater Treatment

\begin{tabular}{llllll}
\hline County & $5^{5} 58$ & - & - & ${ }^{4} 55$ & 10 \\
\hline
\end{tabular}

${ }^{1}$ Data compiled from N.J. Department of Environmental Protection reports.

${ }^{2}$ Includes estimated data.

${ }^{3}$ Withdrawal data compiled from the U. S. Geological Survey, Site-Specific Water-Use Data System.

${ }^{4}$ Includes unaccounted-for water.

${ }^{5}$ Data compiled from U.S. Department of Environmental Protection Agency reports. 
About $2 \mathrm{Mgal} / \mathrm{d}$ of domestic deliveries and about $1 \mathrm{Mgal} / \mathrm{d}$ of all other deliveries of publicly supplied water were estimated to be discharged to onsite wastewater treatment systems. About 31,700 persons receive publicly supplied water and have residential onsite wastewater treatment systems (U.S. Bureau of the Census, 1992). This population value is the the product of the number of households with water-service connections and onsite wastewater treatment systems, 11,500 (Zripko and Hasan, 1994), and the average household size, 2.76 (U.S. Bureau of the Census, 1991). The volume of consumed water is the product of this population, the per capita use of $85 \mathrm{gal} / \mathrm{d}$ that was estimated for domestic users who are publicly supplied, and the nonconsumptive-use coefficient of 0.82 (consumptive-use coefficient of 0.18 for residential users who are publicly supplied).

The volume of non-public supply water conveyed to municipal wastewater treatment plants was estimated to be less than $1 \mathrm{Mgal} / \mathrm{d}$. Most of the self-supplied nonconsumed water (about $7 \mathrm{Mgal} / \mathrm{d}$ ) was discharged to onsite wastewater treatment systems or discharged after treatment directly to a surface-water body (table 10 ).

\section{SUMMARY}

Withdrawals of ground water and surface water in Camden County in 1991 totaled $76 \mathrm{Mgal} / \mathrm{d}$, including about $71 \mathrm{Mgal} / \mathrm{d}$ of ground water and about $5 \mathrm{Mgal} / \mathrm{d}$ of surface water. Withdrawals of ground water by public suppliers totaled $67 \mathrm{Mgal} / \mathrm{d}$. Self-supplied industrial water use, chiefly surface water from the Delaware River, totaled about $4 \mathrm{Mgal} / \mathrm{d}$. Domestic withdrawals totaled about $2 \mathrm{Mgal} / \mathrm{d}$ and accounted for 3 percent of all withdrawals in the county. Irrigation and mining water use totaled about $1 \mathrm{Mgal} / \mathrm{d}$ each, and commercial water use was less than $1 \mathrm{Mgal} / \mathrm{d}$. Most of the withdrawals of ground water in the county were from the PotomacRaritan-Magothy aquifer system, chiefly from the Lower aquifer.

About 80 percent of public-supply withdrawals are metered deliveries. Deliveries include metered water, public water use, and bulk sales to other public suppliers. Deliveries of public suppliers for domestic, commercial, industrial, and public water use were estimated to be $44,9,1$, and $3 \mathrm{Mgal} / \mathrm{d}$, respectively. Water deliveries of public suppliers for residential, commercial, industrial, and public water use accounted for $66,13,2$, and 4 percent, respectively, of total withdrawals by public suppliers.

Per capita use in Camden County was estimated by use of several methods; the results indicate that (1) per capita use is not a single value for all domestic users because residents of single-family housing have more outdoor water use than residents of multifamily housing, (2) per capita use ranges from $57 \mathrm{gal} / \mathrm{d}$ to $124 \mathrm{gal} / \mathrm{d}$, and (3) public suppliers may commonly estimate per capita use by using data on total water withdrawals, instead of using data on domestic deliveries as requested. In this report, per capita use of $84 \mathrm{gal} / \mathrm{d}$ was used to estimate self-supplied domestic withdrawals.

About 99 percent of public-supply withdrawals in the county in 1991 received water treatment; the balance was untreated water that was used for backwashing of pumping equipment and other well-maintenance operations. The distribution losses of public-supply systems in the 
county totaled $9 \mathrm{Mgal} / \mathrm{d}$ or about 13 percent of all public-supply withdrawals. These distribution losses included water leaks, improperly registered meters, unauthorized use of fire hydrants, and illegally connected water meters.

Consumptive water use of all water users in Camden County totaled about $12 \mathrm{Mgal} / \mathrm{d}$ or about 16 percent of all withdrawals in the county. Nonconsumptive water use totaled about $64 \mathrm{Mgal} / \mathrm{d}$ or about 84 percent of all withdrawals in the county.

Wastewater discharges by municipal facilities totaled $58 \mathrm{Mgal} / \mathrm{d}$ in 1990. About $55 \mathrm{Mgal} / \mathrm{d}$ of water from publicly supplied water users was treated and discharged at municipal wastewater treatment facilities. Onsite wastewater treatment totaled about $10 \mathrm{Mgal} / \mathrm{d}$. The difference in the volume of nonconsumed water and the volume discharged at wastewater treatment systems in the county was estimated to be $3 \mathrm{Mgal} / \mathrm{d}$. The additional water in the wastewater treatment systems could be inflow from storm sewers or ground water and additional nonconsumed water from public water users. 


\section{REFERENCES CITED}

American Water Works Association, 1992, WIDB, Water industry data base, Utility profiles: Denver, Colo., American Water Works Association, $116 \mathrm{p}$.

Barksdale, H.C., Greenman, D.W., Lang, S.M., Hillon, G.S., and Outlaw, D.E., 1958, Groundwater resources in the tri-state region adjacent to the lower Delaware River: New Jersey Department of Conservation and Economic Development, Special Report 13, $190 \mathrm{p}$.

Camden County Planning Department, 1972, Water resource and supply primer, Pennsauken, New Jersey: Camden County Planning Department, 24 p.

Camp Dresser \& McKee, 1984a, Population and water demand projections, in Camden metro study: Boston, Mass., Camp Dresser \& McKee, task 3 report, submitted to New Jersey Department of Environmental Protection, $53 \mathrm{p}$.

1984b, Water supply source and analysis, in Camden metro study: Boston, Mass., Camp Dresser \& McKee, task 4 report, submitted to New Jersey Department of Environmental Protection, $52 \mathrm{p}$.

1987, Environmental analysis, in Camden metro study: Boston, Mass., Camp Dresser $\&$ McKee, task 8 report, submitted to New Jersey Department of Environmental Protection, $59 \mathrm{p}$.

Clawges, R.M., and Titus, E.O., 1993, Method for predicting water demand for crop uses in New Jersey in 1990, 2000, 2010, and 2220, and for estimating water use for livestock and selected sectors of the food-processing industry in New Jersey in 1987: U.S. Geological Survey Water-Resources Investigations Report 92-4145, 211 p.

Delaware Valley Regional Planning Commission, 1982, Regional development guide for the Delaware Valley, Philadelphia, Pa.: Delaware Valley Regional Planning Commission, 164 p.

1984, Land use in the Delaware Valley, 1970 and 1980 municipal data in 12 categories, Philadelphia, Pa.: Delaware Valley Regional Planning Commission, $25 \mathrm{p}$.

Ervin, E.M., Voronin, L.M., and Fusillo, T.V., 1994, Water quality of the Potomac-RaritanMagothy aquifer system in the Coastal Plain, west-central New Jersey: U.S. Geological Survey Water-Resources Investigations Report 94-4113, 114 p.

Farlekas, G.M., Nemickas, Bronius, and Gill, H,E., 1976, Geology and ground-water resources of Camden County, New Jersey: U.S. Geological Survey Water-Resources Investigations Report 76-76, $146 \mathrm{p}$.

Harrison, D.K., 1988, New Jersey minerals yearbook, 1988: Washington, D.C., U.S. Government Printing Office, $8 \mathrm{p}$. 


\section{REFERENCES CITED--Continued}

Hazen, Wipple, and Fuller, 1922, Report on water resources of the State and their development: Trenton, N.J., New Jersey Department of Conservation and Development, 76 p.

Merend, Helve, 1989, 1987 New Jersey water withdrawal report: New Jersey Department of Environmental Protection and Energy, $34 \mathrm{p}$.

Navoy, A.S., 1994, Simulated effects of projected withdrawals from the Wenonah-Mount Laurel aquifer on ground-water levels in the Camden, New Jersey, area and vicinity:

U.S. Geological Survey Water-Resources Investigations Report 92-4152, 22 p.

Nawyn, J.P., and Clawges, R.M., 1995, Withdrawals of ground water and surface water in New Jersey, 1989-90, U.S. Geological Survey Open-File Report 94-324, 68 p.

New Jersey Water Policy Commission, 1926, Report of the Water Policy Commission: Trenton, N.J., Parts 1 and 2, 115 p.

New Jersey-American Water Company, 1992, Tri-county water supply project: Water allocation engineer's report, v. 1: Haddon Heights, N.J, submitted to New Jersey Department of Environmental Protection and Energy and Delaware River Basin Commission, variously paged.

Opitz, E.M., Steinbeck, J.R.M., and Dziegielewski, Benedykt, 1994, Application of the IWRMAIN water demand analysis software, version 6.0, selected study areas in the Massachusetts Water Resources Authority service area: Carbondale, Ill., Planning and Management Consultants, Ltd., 112 p.

Ploeser, J.H., Pike, C.W., and Kobrick, J.D., 1992, Nonresidential water conservation--A good investment: Journal American Water Works Association, v. 84, no. 10, p. 65-73.

Principi, V.C., 1991, The State of New Jersey well permit data report: Trenton, N.J., New Jersey Department of Environmental Protection and Energy, $44 \mathrm{p}$.

Qualls, C.L., and Horn, M.A., 1990, New Jersey water supply and use, in Carr, J.E., Chase, E.B., Paulson, R.W., and Moody, D.W., compilers, National water summary 1987--Hydrologic events and water supply and use: U.S. Geological Survey Water-Supply Paper 2350, p. 367-374.

Saarela, Helve, 1992, 1988 New Jersey water withdrawal report: Trenton, N.J., New Jersey Department of Environmental Protection and Energy, 42 p.

Sanders, Welford, and Thurow, Charles, 1982. Water conservation in residential development: Land-use techniques, Planning Advisory Service Report 373, American Planning Association, December 1982, $34 \mathrm{p}$. 


\section{REFERENCES CITED--Continued}

Schefter, J.E., 1990, Trends and associated factors in offstream water use -- Domestic water use in the United States, 1960-85, in Carr, J.E., Chase, E.B., Paulson, R.W., and Moody, D.W., comps., National water summary 1987 -- Hydrologic events and water supply and use:

U.S. Geological Survey Water-Supply Paper 2350, p. 71-80.

Scott, J.P., 1993, Conservation plan for New Jersey American Water Company: Haddon Heights, N.J, submitted to New Jersey Department of Environmental Protection and Energy, 25 p.

Solley, W.B., Pierce, R.R., and Perlman, H.A., 1993, Estimated use of water in the United States in 1990: U.S. Geological Survey Circular 1081, 76 p.

Thompson, D.G. 1932, Ground-water supplies of the Camden area, New Jersey: New Jersey Department of Conservation and Economic Development, Bulletin 39, 80 p.

Tippetts-Abbett-McCartney-Stratton, 1955, Survey of New Jersey water resources development: Trenton, N.J., State of New Jersey Legislative Commission on Water Supply, variously paged.

Titus, E.O., Clawges, R.M., and Qualls, C.L., 1990, Estimated demand for agricultural water for irrigation use in New Jersey, 1990: U.S. Geological Survey Open-File Report 90-156, 23 p.

U.S. Bureau of the Census, 1983a, County and city data book, 1983: Washington, D.C., U.S. Government Printing Office, 996 p.

1983b, Water use in manufacturing, in 1982 census of manufacturers: Washington, D.C., U.S. Government Printing Office, subject series MC82-S-6. 72 p.

1990, Census of manufacturers (1987), geographic areas series: New Jersey: Washington, D.C., U.S. Government Printing Office, MC87-A-31, 95 p.

1991, State and metropolitan area data book, 1991: Washington, D.C., U.S. Government Printing Office, $388 \mathrm{p}$.

1992, Census of population and housing, 1990: Washington,D.C., Summary Tape File 3 on CD-ROM (New Jersey).

1993, County business patterns, 1991, New Jersey: Washington,D.C., U.S. Government Printing Office, CPB-91-32, p. 43-51.

1994a, 1992 Census of agriculture, New Jersey, state and county data: Washington, D.C., U.S. Government Printing Office, 271 p.

1994b, 1994 County and city extra: Annual metro city and county data book: Washington, D.C., U.S. Government Printing Office, 1043 p. 


\section{REFERENCES CITED--Continued}

van der Leeden, Fritz., Troise, F.L., and Todd, D.K., 1990, The water encyclopedia (2d ed.): Chelsea, Mich., Lewis Publishers, 808 p.

Vermeule, C.C., 1894, Report on water-supply, water-power, the flow of streams, and attendant phenomena: Trenton, N.J., Geological Survey of New Jersey, Final Report of the State Geologist, v. 3, 352 p.

Vowinkel, E.F., 1984, Ground-water withdrawals of the Coastal Plain of New Jersey, 1956-80: U.S. Geological Survey Open-File Report 84-226, 32 p.

Zripko, N.P. and Hasan, Asghar, 1994, Depletive water use project for regional water resource planning areas of New Jersey: Trenton, N.J., New Jersey Department of Environmental Protection, $43 \mathrm{p}$. 